\title{
ANALISIS KEBERLANJUTAN PRAKTIK PERTANIAN ORGANIK DI KALANGAN PETANI
}

\author{
Analysis of Sustainability Organic Farming Practise on Farmer \\ Aero Widiarta ${ }^{*}$, Soeryo Adiwibowo, dan Widodo \\ Departemen Sains Komunikasi dan Pengembangan Masyarakat, Fakultas Ekologi Manusia, IPB \\ *)Email : aerowinata@gmail.com \\ Diterima 16 Maret 2011 / Disetujui 30 Maret 2011
}

\begin{abstract}
The objectives of this research are: (1) to analyze the influence of organic farming practice to the economic sustainability of farmers; (2) to compare the complexity level of organic farming practice and conventional farming practice based on farmer's perception; and (3) to investigate causal factors regarding why organic farming practice is not widely adopted by farmers. This research was conducted by using quantitative approach at Ketapang Village, Susukan Subregency, Semarang Regency, Central Java on NovemberDecember 2010. The number of respondents in this research was 79 people from the total population target of farmers. The selected respondents determined through stratified random sampling and simple random sampling technique afterwards. The respondents were devided into two groups: experimental group (organic farmers) and control group (conventional farmers). The kinds of data in this research were: primary quantitative data which collected by spreading questionnaire to the respondents; secondary data from AlBarokah's document; and also supported with primary qualitative data which gathered from in depth interview technique. The data were analyzed by using Paired Samples T-test and Kolmogorov-Smirnov Test, supported with SPSS Program for Windows Version 17.0. The results of this research show that organic farming practice has significant positive influence to the economic sustainability of farmers. Nevertheless, organic farming practice is considered more complex or difficult significantly than conventional farming practice based on control group's perception. Conversely, the fact above doesn't valid for experimental group. There are several causal factors regarding why organic farming practice is not widely adopted by farmers, such as: pragmatic mindset of farmers in viewing organic farming practice and ecological sustainability; farmers are not satisfied if they only use organic fertilizers for rice that make its leaf green color become less visible; organic farming practice doesn't ensure pest-free; the use of organic fertilizer is more difficult than synthetic fertilizer; and a large part of farmers have inadequate supply of manures. Socioeconomic characteristic of farmers consisting of: education level, agricultural land ownership status, and livestock ownership are also revealed as influential factors to the organic farming decision process.
\end{abstract}

Keywords: organic farming practice, farmers, sustainability, analysis.

\section{PENDAHULUAN}

\section{Latar Belakang}

Pertanian organik dipahami sebagai suatu sistem produksi pertanaman yang berazaskan daur ulang hara secara hayati (Sutanto, 2002). Menurut CAC (1999) ${ }^{1}$, pertanian organik merupakan keseluruhan sistem pengelolaan produksi yang mendorong dan mengembangkan kesehatan agro ekosistem, termasuk keanekaragaman hayati, siklus biologis dan aktivitas biologis tanah. Pertanian ini menekankan pada praktik-praktik pengelolaan yang mengutamakan penggunaan input offfarm dan memperhitungkan kondisi regional sistem yang

\footnotetext{
1 Definisi berdasarkan CODEX Alimentarius Commission (CAC) yang dikutip dari http://melileafood.multiply.com/journal/item/6
}

disesuaikan secara lokal. Pertanian organik merupakan salah satu metode produksi yang ramah lingkungan, sehingga dapat menjamin keberlanjutan ekologi, sesuai dengan filosofi "kembali ke alam" atau "selaras dengan alam".

Pertanian organik pada mulanya merupakan sebuah gerakan yang dipopulerkan di Uni Eropa, sebagai wujud perlawanan dari pembangunan pertanian yang berorientasi pada pertumbuhan atau produktivitas yang sering disebut sebagai "Revolusi Hijau". Sistem pertanian organik berusaha memperbaiki dampak negatif dari "Revolusi Hijau" dengan berpijak pada kesuburan tanah sebagai kunci keberhasilan produksi yang memperhatikan kemampuan alami dari tanah, tanaman, dan hewan untuk menghasilkan kualitas yang baik bagi hasil pertanian 
maupun lingkungan. Gerakan organik kemudian berkembang menjadi sebuah filosofi yang diimplementasikan dalam sistem pertanian secara holistik, sehingga muncullah istilah pertanian organik sebagai sebuah alternatif sistem pertanian yang berkelanjutan.

Perkembangan pertanian organik di Indonesia dimulai pada awal 1980-an yang ditandai dengan bertambahnya luas lahan pertanian organik, dan jumlah produsen organik Indonesia dari tahun ke tahun. Berdasarkan data Statistik Pertanian Organik Indonesia (SPOI) yang diterbitkan oleh Aliansi Organis Indonesia (AOI) tahun 2009, diketahui bahwa luas total area pertanian organik di Indonesia tahun 2009 adalah $231.687,11$ ha. Luas area tersebut meliputi luas lahan yang tersertifikasi, yaitu 97.351,60 ha (42 persen dari total luas area pertanian organik di Indonesia) dan luas lahan yang masih dalam proses sertifikasi (pilot project AOI), yaitu 132.764,85 ha (57 persen dari total luas area pertanian organik di Indonesia). Luas total area pertanian organik tahun 2008 jauh lebih besar daripada tahun 2009, yaitu sekitar 235.078,16 ha. Sementara itu, total jumlah pelaku pertanian organik yang tercatat pada tahun 2009 adalah 12.101 produsen yang terdiri dari: 9.628 produsen tersertifikasi, sedangkan sisanya adalah 2.383 produsen non sertifikasi, 80 produsen dalam proses sertifikasi, dan 10 produsen PAMOR (Penjaminan Mutu Organis Indonesia yang merupakan salah satu bentuk sistem sertifikasi partisipasi).

Perkembangan pertanian organik ternyata juga diikuti oleh perkembangan trend atau gaya hidup organik masyarakat yang mensyaratkan konsumsi produk-produk organik. Hal ini kemudian mendorong isu sertifikasi sebagai jaminan atas dipraktikkannya pertanian organik yang menjadi sebuah pembicaraan hangat dari tahun 2003. Semakin terbukanya pasar organik, ternyata masih belum membuat Indonesia cukup mampu menjadi produsen utama produk organik di dunia jika dibandingkan dengan negara-negara lainnya, seperti: India, Amerika Serikat, dan Argentina. Padahal, Indonesia sebagai negara agraris sebenarnya memiliki potensi yang sangat besar untuk menjadi produsen organik di level internasional. Sementara itu, jumlah pelaku pertanian organik di Indonesia yang telah tersertifikasi relatif sedikit, demikian pula dengan jumlah total area pertanian organik di Indonesia yang masih perlu ditingkatkan lagi.

Rendahnya jumlah produsen dan luas lahan organik di Indonesia khususnya di kalangan petani, ternyata tidak hanya sekedar isapan jempol yang dilaporkan dalam datadata statistik, tetapi juga diperkuat oleh bukti nyata di lapangan yang didapatkan oleh penulis selama survey pra penelitian. Berdasarkan survey lapang pada bulan Juni hingga Juli 2010 di wilayah Kota dan Kabupaten Bogor, diketahui bahwa jumlah petani organik di setiap desa yang dikunjungi, seperti: Desa Cibatok, Desa Cibereum Situleutik, Kelurahan Situgede, Kelurahan Mulyaharja, dan Kelurahan Sukaharja, sangat sedikit dibandingkan petani konvensional. Jumlah tersebut hanya berkisar antara tiga sampai tiga belas orang petani organik per desa. Sedangkan jumlah petani konvensional, relatif lebih banyak dibandingkan petani organik, yaitu lebih dari dua puluh orang petani per desanya meskipun belum ada laporan statistik secara resmi di tiap desa mengenai hal ini. Realita tersebut sangat ironis atau bertolak belakang dengan teori pertanian organik yang dikemukakan oleh para ahli. Banyak referensi atau teori yang menyatakan bahwa pertanian organik berpengaruh positif terhadap keberlanjutan ekologi, dan ekonomi petani. Namun, pada kenyataannya masih banyak petani yang belum menjalankan praktik pertanian organik dan cenderung mempertahankan praktik pertanian konvensional. Perbedaan nyata antara teori dengan realita praktik pertanian organik di kalangan petani inilah kemudian menimbulkan pertanyaan besar yang penting untuk diteliti lebih lanjut.

Analisis keberlanjutan praktik pertanian organik di kalangan petani kemudian menjadi salah satu hal yang dapat dilakukan untuk menjawab fenomena di atas. Keberlanjutan praktik pertanian organik di kalangan petani memang perlu dipertanyakan karena masih sedikitnya jumlah petani organik di Indonesia. Analisis keberlanjutan praktik pertanian organik, dapat dilihat dari aspek ekonomi, tingkat kompleksitas praktik budidayanya, dan alasan petani mengapa mereka belum menerapkan praktik pertanian organik secara luas, sehingga pertanian organik belum begitu berkembang di kalangan mereka. Analisis tersebut sangat memungkinkan dilakukan pada komunitas petani organik yang telah menjalankan praktik pertanian organik lebih dari tiga tahun di suatu desa, seperti Desa Ketapang, lalu membandingkannya dengan praktik pertanian konvensional di kalangan petani konvensional pada lokasi yang sama. Analisis keberlanjutan praktik pertanian organik di kalangan petani, menjadi penting untuk diteliti karena jika tidak segera diteliti, maka fenomena pertanian organik yang belum berkembang di kalangan petani Indonesia, akan terus menjadi pertanyaan besar yang tidak akan terjawab. Selain itu, ketersediaan data atau laporan penelitian mengenai pertanian organik di Indonesia masih kurang, sehingga dapat menghambat perkembangan informasi seputar pertanian organik khususnya di kalangan petani.

\section{Perumusan Masalah}

Berdasarkan latar belakang yang telah dipaparkan tersebut, maka perumusan masalah dari penelitian ini adalah:

1) Bagaimana pengaruh praktik pertanian organik terhadap keberlanjutan ekonomi petani?

2) Seberapa tinggi tingkat kompleksitas praktik pertanian organik dibandingkan dengan pertanian konvensional menurut petani?

3) Mengapa praktik pertanian organik tidak banyak diadopsi oleh petani?

\section{Tujuan Penelitian}

Tujuan dari penelitian ini, adalah:

1) Mengetahui pengaruh praktik pertanian organik terhadap keberlanjutan ekonomi petani.

2) Menganalisis tingkat kompleksitas praktik pertanian organik dibandingkan dengan pertanian konvensional menurut petani. 
3) Menjelaskan faktor-faktor penyebab praktik pertanian organik tidak banyak diadopsi oleh petani.

\section{PENDEKATAN LAPANGAN}

\section{Metode Penelitian}

Penelitian ini merupakan penelitian yang bersifat menjelajah (exploratory) karena bertujuan untuk mengenal pengetahuan mengenai suatu gejala tertentu yang masih baru dan memuaskan keingintahuan peneliti untuk memperoleh pemahaman yang lebih baik (Wahyuni dan Muljono, 2007). Berdasarkan jenisnya, penelitian ini secara umum termasuk penelitian survey eksperimental karena data dikumpulkan dari responden atau sampel suatu populasi dengan menggunakan kuesioner serta berusaha mengetahui hubungan sebab akibat variabel penelitian sebagai konsekuensi dari suatu tindakan/aksi dalam dua kelompok yang berbeda, yaitu experimental dan control group (Singarimbun dan Effendi, 2006). Selain itu, penelitian ini juga bisa dikatakan sebagai penelitian kausal komparatif yang bermaksud mencari kemungkinan hubungan sebab akibat dan mencari kesamaan atau perbedaan kelompok dengan menggunakan data yang ada (Usman dan Akbar, 2008).

Penelitian ini dilakukan dengan menggunakan metode kuantitatif yang didukung oleh data kualitatif. Metode kuantitatif yang digunakan dalam penelitian ini, berperan sebagai landasan atau dasar penelitian untuk menguji hipotesis yang kemudian diperkuat dengan data kualitatif. Data kualitatif berfungsi untuk menjelaskan atau memperkuat fakta yang tidak bisa dijelaskan secara kuantitatif. Data kualitatif juga bertujuan untuk menjawab perumusan masalah penelitian yang bersifat mendalam, yaitu perumusan masalah ketiga dalam penelitian ini.

\section{Lokasi dan Waktu Penelitian}

Pemilihan lokasi penelitian dilakukan secara sengaja (purposive), yaitu di Paguyuban Petani Al-Barokah, Desa Ketapang, Kecamatan Susukan, Kabupaten Semarang, Propinsi Jawa Tengah. Dimensi waktu penelitian ini adalah cross-sectional karena penelitian ini hanya dilakukan pada bulan November hingga Desember 2010. Beberapa alasan pemilihan lokasi tersebut, antara lain:

1) Desa Ketapang, Kecamatan Susukan, Kabupaten Semarang, merupakan salah satu desa di Jawa Tengah yang memiliki area pertanian organik dan komunitas petani organik maupun konvensional cukup banyak sesuai dengan kebutuhan penelitian. Petani organik dan konvensional yang menjadi sasaran penelitian ini, tergabung dalam sebuah Paguyuban Petani bernama Al-Barokah yang berada dalam satu desa.

2) Praktik pertanian organik sudah dilakukan oleh para petani sejak tahun 1998 atau minimal telah lebih dari 3 tahun di Desa Ketapang, Kecamatan Susukan, Kabupaten Semarang, sehingga pengaruh praktik pertanian organik terhadap keberlanjutan ekonomi petani dapat diukur secara nyata. Paguyuban Petani Al-Barokah juga memiliki banyak prestasi, baik di tingkat propinsi maupun nasional terkait dengan pengembangan pertanian organik. Komoditas yang dibudidayakan oleh petani di desa tersebut adalah padi sawah. Berdasarkan pertimbangan tersebut, maka lokasi penelitian ini sangat tepat dipilih.

\section{Teknik Pengumpulan Data}

Jenis data yang digunakan dalam penelitian ini adalah data kuantitatif dan data kualitatif yang dikumpulkan melalui teknik pengumpulan data sesuai dengan masingmasing jenis data. Sumber data yang dikumpulkan adalah data primer dan sekunder. Data primer merupakan data yang didapatkan langsung dari responden atau informan. Sebaliknya, data sekunder merupakan data yang diperoleh secara tidak langsung melalui pihak lain atau penelusuran dokumen. Teknik pengambilan data pada metode kuantitatif, dilakukan dengan cara menyebar kuesioner kepada responden penelitian. Sedangkan teknik pengambilan data kualitatif, dilakukan melalui wawancara mendalam dengan informan terkait dan responden; serta teknik dokumentasi dengan cara menganalisis atau menelusuri dokumen terkait penelitian. Berdasarkan teknik pengumpulan data yang telah dijelaskan, maka instrumen penelitian ini adalah instrumen non-tes berupa kuesioner dan pedoman wawancara.

\section{Teknik Pengambilan Responden dan Informan}

Unit analisis penelitian ini adalah individu. Responden penelitian ini adalah petani organik yang telah melaksanakan praktik pertanian organik lebih dari tiga tahun dengan tanaman budidaya padi sawah dan petani konvensional sebagai responden kontrol yang berada pada lokasi dan tergabung dalam paguyuban petani yang sama dengan petani organik. Jumlah total populasi petani di Desa Ketapang (populasi sampling) mencapai 2.347 orang, sedangkan jumlah total populasi petani yang tergabung dalam Paguyuban Petani Al-Barokah (populasi sasaran) adalah 372 orang. Populasi sasaran tersebut terdiri dari dua sub populasi (strata), yaitu: 14 orang petani organik, dan 358 orang petani

konvensional. Penelitian ini menggunakan metode survey eksperimen yang membutuhkan sampel dari populasi, yaitu dua kelompok responden penelitian, yang terdiri dari: kelompok eksperimen (experimental group) dan kelompok kontrol (control group) dengan jumlah tertentu karena jumlah populasi terlalu besar jika diteliti. Banyaknya jumlah responden penelitian yang dapat mewakili populasi, ditentukan dari perhitungan rumus Slovin dan didapatkan ada 79 orang responden penelitian.

Teknik pengambilan responden pada penelitian ini dilakukan secara acak distratifikasi (stratified random sampling) karena populasi tidak homogen, yaitu terdiri dari dua sub populasi, seperti sub populasi petani organik dan konvensional. Dari semua sub populasi atau kelas tersebut, kemudian masing-masing diambil perwakilan respondennya dengan perhitungan sebagai berikut:
1) Petani organik $=14$ orang karena merupakan jumlah total sub populasi.
2) Petani konvensional $=79-14=65$ orang.

Informan yang dipilih untuk penelitian ini adalah orang yang memahami Paguyuban Petani Al-Barokah dan telah ikut berkecimpung dalam perkembangan pertanian organik di Desa Ketapang. Pemilihan informan tersebut 
dilakukan secara sengaja (purposive) dan mereka adalah Pak Mustofa, mantan ketua Paguyuban Petani AlBarokah; Pak Muslikh, Ketua Paguyuban Petani AlBarokah yang baru; Pak Basirun; serta beberapa tokoh masyarakat Desa Ketapang. Informan ini diperlukan sebagai pemberi informasi atau data tambahan terkait dengan penelitian yang tidak dapat diperoleh melalui kuesioner.

\section{Teknik Pengolahan dan Analisis Data}

Teknik pengolahan dan analisis data dalam penelitian ini dilakukan dengan perlakuan yang berbeda sesuai jenis data yang diperoleh dan jenis hipotesisnya. Menurut Miles and Huberman (1984) dalam Sugiyono (2009), data kualitatif akan diolah melalui tiga tahap analisis, yaitu reduksi data (data reduction), penyajian data (data display) dan penarikan kesimpulan (conclusion drawing). Penjelasan mengenai tahap-tahap tersebut, antara lain:

1) Reduksi data: merangkum, memilih hal-hal pokok, memfokuskan pada hal-hal penting sesuai dengan kebutuhan penelitian.

2) Penyajian data: menyajikan data dalam bentuk uraian singkat dan kutipan langsung untuk mendukung data kuantitatif.

3) Penarikan kesimpulan yang menghasilkan temuan baru atas obyek penelitian.

Data primer yang diperoleh melalui metode kuantitatif, yaitu hasil penyebaran kuesioner di lapangan, terlebih dahulu akan dilakukan proses editing, pengkodean, selanjutnya dilakukan pemindahan dari daftar pertanyaan ke buku kode dalam bentuk tabel Microsoft Excell 2007 yang telah disiapkan. Data-data tersebut kemudian diolah menggunakan program SPSS 17.0 for Windows dan diuji secara statistik. Uji statistik yang digunakan adalah Paired Samples T-test yang bertujuan untuk menguji hipotesis pertama penelitian ini. Selain itu, penelitian ini juga menggunakan uji non parametrik dua Independent Samples Test, yaitu Uji Kolmogorov-Smirnov untuk menguji hipotesis kedua penelitian ini, sehingga tingkat kompleksitas praktik pertanian organik dapat dibandingkan dengan praktik pertanian konvensional menurut persepsi petani pada dua kelompok berbeda (Experimental Group dan Control Group).

\section{Kerangka Pemikiran}

Berdasarkan kriteria pertanian berkelanjutan, analisis keberlanjutan praktik pertanian organik di kalangan petani dapat dilakukan dengan mengidentifikasi pengaruh praktik pertanian organik terhadap keberlanjutan ekonomi petani dan mengukur tingkat kompleksitas praktik pertanian organik menurut persepsi petani. Pengaruh praktik pertanian organik terhadap keberlanjutan ekonomi petani dianalisis dengan metode survey eksperimen, sehingga perubahan terhadap aspek ekonomi petani terlihat jelas. Metode ini berusaha membandingkan kondisi ekonomi petani yang dilihat dari keuntungan
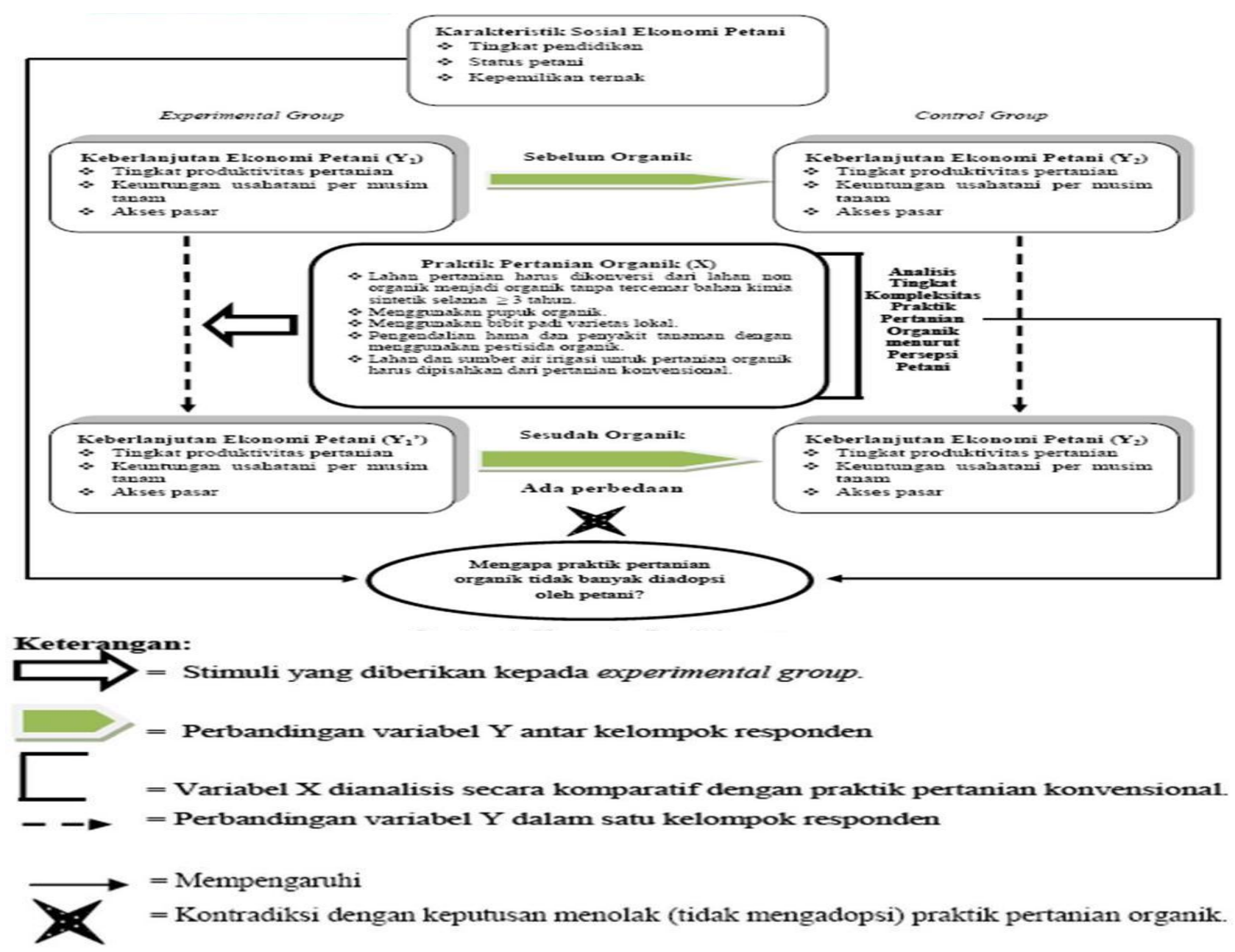
usahataninya pada saat sebelum dan sesudah adanya praktik pertanian organik melalui kuesioner. Responden penelitian meliputi control group, yaitu kelompok petani non organik (konvensional) yang dijadikan sebagai responden kontrol atau pembanding dan experimental group, yaitu kelompok petani organik yang dijadikan sebagai responden eksperimen. Jenis tanaman budidaya dalam sistem usahatani organik dan konvensional yang akan diteliti adalah padi sawah. Bentuk kerangka pemikiran penelitian ini, secara lengkap dapat dilihat pada Gambar 1.

Praktik pertanian organik menurut Sutanto (2002), sangat tergantung dari pengetahuan lokal petani dan kondisi pertanian setempat. Namun, secara umum praktik pertanian organik yang paling mudah dilakukan dan diukur di kalangan petani, meliputi: penggunaan pupuk organik, penggunaan bibit varietas lokal, pengendalian hama dan penyakit tanaman dengan menggunakan pestisida organik, serta pemisahan lahan dan sumber air irigasi pertanian organik dari pertanian konvensional. Praktik pertanian organik seperti yang telah disebutkan di atas, merupakan ketentuan minimal yang harus dipenuhi oleh petani jika ingin diakui sebagai petani organik. Hal ini disebabkan karena pertanian organik, tidak hanya dilihat dari penggunaan pupuk organik saja, tetapi banyak aspek yang dinilai, termasuk sikap petani sendiri terhadap alam. Selain itu, suatu lahan pertanian organik benarbenar akan terbebas dari residu kimia sintetik dan mampu berproduksi secara stabil atau optimal, jika telah mengalami masa konversi dari lahan non organik menjadi organik tanpa tercemar bahan kimia sintetik selama minimal tiga tahun atau lebih.

Praktik pertanian organik dalam penelitian ini selanjutnya disebut sebagai variabel bebas atau variabel pengaruh (independent variabel) yang diberi lambang $\mathrm{X}$. Variabel ini akan diuji pengaruhnya terhadap variabel lainnya, yaitu variabel tidak bebas atau terikat (dependent variabel). Variabel terikat yang dimaksud dalam penelitian ini adalah keberlanjutan ekonomi (Y) yang memiliki beberapa indikator, antara lain: tingkat produktivitas pertanian, keuntungan usahatani per musim tanam, dan akses pasar. Pengaruh $\mathrm{X}$ terhadap $\mathrm{Y}$ dapat diketahui dengan membandingkan nilai variabel $\mathrm{Y} 1$ dengan Y2 antar kelompok responden pada kondisi sebelum organik, Y1 ${ }^{\text {ee }}$ dengan $\mathrm{Y} 2$ antar kelompok responden pada kondisi sesudah organik dan Y1 dengan $\mathrm{Y}^{\mathrm{ee}}$ dalam kelompok eksperimen. Hubungan antar variabel bersifat asimetris yang menunjukkan hubungan antara stimulus dengan respons dan merupakan hubungan bivariat, yaitu hubungan antara satu variabel bebas dengan satu variabel terikat. Pengaruh variabel $\mathrm{X}$ terhadap variabel $\mathrm{Y}$ menjadi penting untuk diuji agar dapat diketahui sampai sejauh mana praktik pertanian organik berpengaruh terhadap keberlanjutan ekonomi petani. Jika $\mathrm{X}$ terbukti berpengaruh terhadap $\mathrm{Y}$, maka akan terjadi perbedaan nilai $Y$ antara petani yang menjalankan sistem usahatani organik dengan konvensional. Menurut tinjauan pustaka, praktik pertanian organik terbukti berpengaruh positif terhadap keberlanjutan ekonomi petani. Namun, ironisnya hal ini berkontradiksi dengan banyaknya keputusan para petani yang menolak atau tidak mengadopsi praktik pertanian organik.

Analisis tingkat kompleksitas praktik pertanian organik (variabel $\mathrm{X}$ ) menurut persepsi petani, juga penting diketahui karena bisa menjadi salah satu alasan kuat mengapa praktik pertanian organik tidak banyak diadopsi oleh petani di suatu daerah. Bentuk analisis terhadap variabel $\mathrm{X}$, bersifat komparatif karena membandingkan tingkat kompleksitas antara praktik pertanian organik dengan praktik pertanian konvensional menurut dua kelompok responden. Meskipun demikian, masih terdapat kemungkinan adanya penyebab lain mengapa praktik pertanian organik belum berkembang di kalangan petani, seperti pengaruh variabel antesenden terhadap pengambilan keputusan inovasi, yaitu karakteristik sosial ekonomi petani yang terdiri dari: tingkat pendidikan, status petani dan kepemilikan ternak. Penyebab lain di luar analisis statistik, akan diinvestigasi lebih dalam secara kualitatif. Hasil penelitian ini secara keseluruhan, dapat digunakan sebagai referensi mengenai bukti keberlanjutan praktik pertanian organik di kalangan petani yang kemudian menjawab sebuah pertanyaan besar, yaitu mengapa pertanian organik masih belum banyak diadopsi oleh petani. Setelah mengetahui hasil penelitian ini, diharapkan akan ada tindak lanjut atau kebijakan pembangunan pertanian dari para stakeholders, khususnya pemerintah pada masa yang akan datang.

\section{Hipotesis Penelitian}

\section{Hipotesis Uji}

Berdasarkan kerangka pemikiran yang telah dibuat, penelitian ini mempunyai beberapa hipotesis kerja yang akan diuji, antara lain:

1) Praktik pertanian organik (X) diduga berpengaruh positif secara signifikan terhadap keberlanjutan ekonomi petani (Y).

2) Tingkat kompleksitas praktik pertanian organik diduga lebih tinggi secara signifikan daripada praktik pertanian konvensional menurut persepsi petani.

\section{Hipotesis Pengarah}

Praktik pertanian organik tidak banyak diadopsi oleh para petani karena diduga memiliki tingkat kompleksitas yang lebih tinggi dibandingkan praktik pertanian konvensional dan dipengaruhi oleh karakteristik sosial ekonomi petani. 


\section{Definisi Operasional}

Tabel 1. Definisi Operasional untuk Analisis Pengaruh Praltik Pertanian Organik (Variabel X) terhadap Keberlanjutan Ekonomi Petani (Variabel Y)

\begin{tabular}{|c|c|c|c|}
\hline Variabel/Indilcator & Definisi Operasional & Kategori & Skala Penguluran \\
\hline Praktik Pertanian Organik (X): & $\begin{array}{l}\text { Teknik budidaya pertanian yang menggunakan sumber daya alam secara organdk atau } \\
\text { terbebas dari penggunaan input kimia sintetik dan dilakukan oled petani sesuai dengan } \\
\text { pengetahuan dan koudisi lokal mereka. }\end{array}$ & $\begin{array}{l}\text { Organik = 1, jika indikato: } \\
\text { a-e terpenubi. } \\
\text { Konvensional = 2, jika } \\
\text { salab san dari indikato: a- } \\
\text { e tidak terpenuhi. }\end{array}$ & Nominal \\
\hline $\begin{array}{l}\text { a. Laban pertanian hanus dikonversi dari non } \\
\text { organik menjadi organik tanpa tercemar baban } \\
\text { kimia sintetik selama } \geq 3 \text { tahun. }\end{array}$ & $\begin{array}{l}\text { Periode yang dibutuhkan untuk mengkonversi laban dari non-organik menjadi organik, } \\
\text { sebingga laban terbebas dari residu bahan kimia sintetik secara ideal selama minimal } 3 \\
\text { tabun. }\end{array}$ & $\begin{array}{l}Y_{3}=1 \\
\text { Tidak }=2\end{array}$ & Nomina! \\
\hline b. Menggunakan pupuk organd. & $\begin{array}{l}\text { Petani mengguakan pupuk yang berasa! dari baban organik seperti pupuk kompos, } \\
\text { kandang, hijau, dan lain-lain. }\end{array}$ & $\begin{array}{l}Y_{3}=1 \\
\text { Tidak }=2\end{array}$ & Nomina! \\
\hline c. Menggunakan bibit padi varietas lokal. & Petani menggunakan bibit padi rarietas lokal, bukan bibrida atan hasil rekayasa genetika. & $\begin{array}{l}Y_{\mathrm{a}}=1 \\
\text { Tidak }=2\end{array}$ & Nomina! \\
\hline $\begin{array}{l}\text { d. Pengendalian bama dan penyakit tanaman } \\
\text { dengan menggunakan pestisida organik. }\end{array}$ & $\begin{array}{l}\text { Pengendalian bama dan penyakit tanaman secara alami yang dapat dilakukan oleb petani } \\
\text { dengan memanfaatkan pestisida hayati atau nabati; serta predator hama alami tanpa baban } \\
\text { kimia sintetik. }\end{array}$ & $\begin{array}{l}\mathrm{Ya}=1 \\
\text { Tidak }=2\end{array}$ & Nomina! \\
\hline $\begin{array}{l}\text { e. Laban dan sumber air ingasi untuk pertanian } \\
\text { organik banus dipisablan dari pertanian } \\
\text { konvensional. }\end{array}$ & $\begin{array}{l}\text { Penitaban lahan dan sumber air irigasi antara pertanian organik dengan pertanian } \\
\text { konveasional untuk menghindari kontaminasi baban-baban kimia sinterk. }\end{array}$ & $\begin{array}{l}\mathrm{Ya}_{\mathrm{a}}=1 \\
\text { Tidak }=2\end{array}$ & Nomina! \\
\hline Keberlanjutan Ekonomi Petani (Y): & $\begin{array}{l}\text { Kondisi ekonomi petani yang ideal, yain jika petani mampu mencukupi kebundan } \\
\text { mereka dan memperoleh pendapatan yang culup untuk melaksanakan keberlanjutan } \\
\text { peughidupan secara koutinu. }\end{array}$ & $\begin{array}{l}\text { Berlanjut secara signifikan } \\
\text { jika ada perbedaan yang } \\
\text { cukup nyata antara kondisi } \\
\text { ekonomi petani sebelum } \\
\text { dan sesudab melaksanakan } \\
\text { pertanian organik, serta } \\
\text { antara kondisi ekonomi } \\
\text { petani organik dengan } \\
\text { konvensional. }\end{array}$ & Rasio \\
\hline a. Tingkat produksi pertanian & $\begin{array}{l}\text { Kemampuan sistem usabatani dalam mengbasilkan panen per luas laban pada musim } \\
\text { tertenn dan tanaman yang dibudidayakan untuk meajamin kelangsungan bidup petan. }\end{array}$ & $\begin{array}{l}\text { Jumlah basil paren } \\
\text { dhitung per luas laban } \\
\text { yang digarap oled petani } \\
\text { per musim dengan sanuan } \\
\mathrm{kg}\end{array}$ & Rasio \\
\hline b. Keunnugan usabatani per musim tanam & $\begin{array}{l}\text { Jumlab total pendapatan petani per musim tanam dikurangi jumlah total biaya input } \\
\text { produksi pertanian. }\end{array}$ & $\begin{array}{l}\text { Keuntugan dikinug } \\
\text { dalam saman Rupiab (R.p) }\end{array}$ & Rasio \\
\hline c. Akses pasar & $\begin{array}{l}\text { Kemampuan atau peluang petani dalam memasarkan atau menjual produk pertaniannya } \\
\text { kepada konsumen melalui berbagai macam saluran dismbusi berdasarkan permintasn } \\
\text { konsumen. Akses pasar dinilai dan banyak dan terbukanya saluran distribusi yang bisa } \\
\text { djangkau oleb petani sendin dengan otontas barga jual produk dari petani. }\end{array}$ & & \\
\hline
\end{tabular}

Tabel 2. Definisi Operasional untuk Analisis Tingkat Kompleksitas Praktik Pertanian Organik (Variabel X) Menurut Persepsi Petani

\begin{tabular}{|c|c|c|c|}
\hline Variabel/Indilator & Definisi Operasional & Kategori & Slkala Pengulkuran \\
\hline Praktik Pertanian Organik $(\mathrm{X})$ : & $\begin{array}{l}\text { Teknik budidaya pertanian yang menggunakan sumber daya alam secara organik atau } \\
\text { terbebas dan penggunaan input kimia dan dilakukan oleh petani sesuai dengan } \\
\text { pengetahuan dan kondisi lokal mereka. }\end{array}$ & $\begin{array}{l}1=\text { sangat mudah } \\
2=\text { mudab } \\
3=\text { biasa saja } \\
4=\text { sulit } \\
5=\text { sangat sulit }\end{array}$ & Ordinal \\
\hline $\begin{array}{l}\text { a. Laban pertanian barus dikontersi dari laban } \\
\text { non organik menjadi organik tanpa tercemar } \\
\text { bahan kimia sintetik selama } \geq 3 \text { tahun (v1) }\end{array}$ & $\begin{array}{l}\text { Periode yang dibutuhkan untuk mengkonversi laban dari non-organik menjadi organik, } \\
\text { sebingga laban terbebas dari residu bahan kimia sirtetk secara ideal selama minimal } 3 \\
\text { tabun. }\end{array}$ & $\begin{array}{l}1=\text { sangat singkat } \\
2=\text { singkat } \\
3=\text { sedang } \\
4=\text { lama } \\
5=\text { sangat lama }\end{array}$ & Ordinal \\
\hline $\begin{array}{l}\text { b. Proses mendapatkan dan mengangkut pupuk } \\
\text { organik ke sawah secara rutin setiap musim } \\
\text { (v2) }\end{array}$ & $\begin{array}{l}\text { Cara petani mendapatkan dan menganghut pupuk yang berasal dari bahan organik seperti } \\
\text { pupuk kompos, kandang, hijau, cair, dan lain-lain dari lokasi awal mereka menuju ke } \\
\text { sawab secara rutin setiap musim. }\end{array}$ & $\begin{array}{l}1=\text { sangat mudah } \\
2=\text { mudab } \\
3=\text { biasa saja } \\
4=\text { sulit } \\
5=\text { sangat sulit }\end{array}$ & Ordinal \\
\hline c. Harga beli bibit padi varietas lokal (v3) & $\begin{array}{l}\text { Harga yang harus dibayar olè petani dalam menggunakan bibit padi varietas lokal, bukan } \\
\text { hibrida atau hasil rekayasa genetika. }\end{array}$ & $\begin{array}{l}1=\text { sangat murab } \\
2=\text { murah } \\
3=\text { sedang } \\
4=\text { mahal } \\
5=\text { sangat mahal }\end{array}$ & Ordinal \\
\hline $\begin{array}{l}\text { d. Pengendalian hama dan penyakit tanaman } \\
\text { dengan menggunakan pestisida organik }(v 4)\end{array}$ & $\begin{array}{l}\text { Pengendalian bama dan penyakit tanaman secara alami yang dapat dilakukan oleh petani } \\
\text { dengan memanfaatkan pestisida bayati atau nabati; serta predator hama alami tappa baban } \\
\text { kimia sinterik. }\end{array}$ & $\begin{array}{l}1=\text { sangat mudah } \\
2=\text { mudab } \\
3=\text { biasa saja } \\
4=\text { sulit } \\
5=\text { sangat sulit }\end{array}$ & Ordinal \\
\hline $\begin{array}{l}\text { e. Lahan dan sumber air irigasi untuk pertanian } \\
\text { organik barus dipisabkan dari pertanian } \\
\text { konvensional (v5) }\end{array}$ & $\begin{array}{l}\text { Pemisaban làan dan sumber air irigasi antara pertanian organik dengan pertanian } \\
\text { konvensional untuk menghindari kontaminasi baban-baban kimia sintetik. }\end{array}$ & $\begin{array}{l}1=\text { sangat mudah } \\
2=\text { mudah } \\
3=\text { biasa saja } \\
4=\text { sulit } \\
5=\text { sangat sulit }\end{array}$ & Ordinal \\
\hline
\end{tabular}




\section{GAMBARAN UMUM LOKASI PENELITIAN}

Desa Ketapang merupakan salah satu desa yang berada dalam wilayah administratif Kecamatan Susukan, Kabupaten Semarang, Propinsi Jawa Tengah. Desa ini memiliki suhu rata-rata harian sekitar $27^{\circ}-29^{\circ} \mathrm{C}$ dengan curah hujan rata-rata $21 \mathrm{~mm}$ per tahun. Batas wilayah Desa Ketapang adalah sebagai berikut: sebelah utara berbatasan dengan Desa Sidoharjo; sebelah selatan berbatasan dengan Desa Timpik-Tawang; sebelah barat berbatasan dengan Desa Susukan; dan sebelah timur berbatasan dengan Desa Gentan-Bakalrejo. Desa Ketapang termasuk daerah dataran tinggi yang berada pada ketinggian $613 \mathrm{~m}$ di atas permukaan laut dengan jarak: $1 \mathrm{~km}$ dari Ibu Kota Kecamatan, $48 \mathrm{~km}$ dari Ibu Kota Kabupaten, 75 km dari Ibu Kota Propinsi dan 1000 $\mathrm{km}$ dari Ibu Kota Negara. Desa Ketapang terdiri dari 6 Rukun Warga (RW), 5 dusun, 31 Rukun Tetangga (RT) dengan luas total wilayah sebesar 327 ha. Sebagian besar luas wilayah desa digunakan untuk area persawahan, sedangkan sisanya digunakan untuk pemukiman dan bangunan, tegalan, fasilitas umum, lapangan olahraga, dan kuburan. Sebagian besar mata pencaharian penduduk Desa Ketapang adalah petani dengan persentase 69,7 persen dari jumlah jumlah total penduduk Desa Ketapang yang bekerja.

\section{KARAKTERISTIK \\ SOSIAL \\ EKONOMI RESPONDEN}

\section{Tingkat Pendidikan}

Tingkat pendidikan responden cukup bervariasi, mulai dari tidak tamat Sekolah Dasar (SD), tamat SD, tamat Sekolah Menengah Pertama (SMP)/sederajat, tamat Sekolah Menengah Atas (SMA)/sederajat, dan tamat Perguruan Tinggi (PT) dengan gelar sarjana. Tingkat pendidikan responden masih rendah karena terbukti dari banyaknya responden yang hanya tamat SD dibandingkan dengan jenjang pendidikan yang lebih tinggi. Jumlah responden dengan tingkat pendidikan terakhir tamat SD mencapai 45 orang atau 57 persen dari jumlah total responden (Tabel 3). Persentase tersebut merupakan persentase tertinggi diantara persentase jumlah responden pada masing-masing tingkat pendidikan.

Persentase jumlah responden eksperimen dan kontrol yang tidak lulus SD masing-masing sebesar 35,7 persen dan 18,5 persen dari jumlah total responden pada masingmasing kelompok. Sementara itu, persentase jumlah responden eksperimen dan kontrol yang tingkat pendidikannya termasuk dalam kategori sedang hingga tinggi (lulus SMP/Sederajat hingga Perguruan Tinggi), masing-masing adalah 42,9 persen dan 16,9 persen dari jumlah total responden pada masing-masing kelompok. Hal ini membuktikan bahwa tingkat pendidikan responden eksperimen (petani organik) lebih tinggi daripada responden kontrol (petani konvensional), meskipun persentase jumlah responden eksperimen yang tidak lulus SD lebih besar daripada responden kontrol. Untuk keterangan lebih lanjut mengenai jumlah dan persentase responden penelitian berdasarkan tingkat pendidikan, dapat dilihat pada Tabel 3.
Tabel 3. Jumlah dan Persentase Responden Penelitian Berdasarkan Tingkat Pendidikan di Desa Ketapang, Tahun 2010

\begin{tabular}{|l|c|c|c|c|c|c|}
\hline \multirow{2}{*}{$\begin{array}{c}\text { Tingkat } \\
\text { Pendidikan }\end{array}$} & \multicolumn{2}{|c|}{$\begin{array}{c}\text { Petani Organik } \\
\mathrm{n}=14\end{array}$} & \multicolumn{2}{c|}{$\begin{array}{c}\text { Petani Konvensional } \\
\mathrm{n}=\mathbf{6 5}\end{array}$} & \multicolumn{2}{c|}{$\begin{array}{c}\text { Total Responden } \\
\mathrm{n}=79\end{array}$} \\
\cline { 2 - 7 } & $\begin{array}{c}\text { Jumlah } \\
(\text { Orang) }\end{array}$ & $\begin{array}{c}\text { Persentase } \\
(\%)\end{array}$ & $\begin{array}{c}\text { Jumlah } \\
(\text { Orang) }\end{array}$ & $\begin{array}{c}\text { Persentase } \\
(\%)\end{array}$ & $\begin{array}{c}\text { Jumlah } \\
(\text { Orang })\end{array}$ & $\begin{array}{c}\text { Persentase } \\
(\%)\end{array}$ \\
\hline Tidak Lulus SD & 5 & 35,7 & 12 & 18,5 & 17 & 21,5 \\
\hline SD & 3 & 21,4 & 42 & 64,6 & 45 & 57 \\
\hline SMP Sederajat & 2 & 14,3 & 9 & 13,8 & 11 & 13,9 \\
\hline SMA/Sederajat & 3 & 21,4 & 2 & 3,1 & 5 & 6,3 \\
\hline Sarjana & 1 & 7,1 & 0 & 0 & 1 & 1,3 \\
\hline Total & 14 & 100 & 65 & 100 & 79 & 100 \\
\hline Sumber: Data Primer Diolah & & & & &
\end{tabular}

\section{Status Petani}

Status petani yang dimaksud dalam penelitian ini adalah petani pemilik lahan, petani penggarap atau buruh tani dan petani pemilik lahan sekaligus penggarap atau petani berstatus ganda. Petani pemilik lahan adalah petani yang memiliki lahan pertanian (sawah) sendiri, baik sawah yang dikelola sendiri maupun dikelola oleh orang lain. Petani penggarap adalah petani yang tidak mempunyai lahan pertanian (sawah) tetapi menggarap atau mengelola sawah milik orang lain dengan sistem bagi hasil panen sebesar 50 persen. Semua biaya produksi pertanian ditanggung oleh petani penggarap. Petani berstatus ganda adalah petani yang selain memiliki lahan pertanian (sawah) tetapi juga menggarap sawah milik orang lain untuk menambah pemasukan usahataninya. Berdasarkan Tabel 4, sebagian besar responden memiliki lahan pertanian atau sawah sendiri, yaitu sejumlah 50 orang dari jumlah total responden penelitian yang terbagi menjadi: 40 orang petani pemilik lahan, dan 10 orang petani berstatus ganda (pemilik lahan dan penggarap).

Persentase jumlah responden eksperimen dan kontrol yang memiliki lahan pertanian atau sawah sendiri, masing-masing adalah 78,6 persen dan 60 persen dari jumlah total responden pada setiap kelompok. Sementara itu, persentase jumlah responden kontrol yang berstatus sebagai petani penggarap/buruh tani mencapai 40 persen dari jumlah total responden kontrol. Persentase tersebut lebih besar daripada persentase jumlah responden eksperimen yang berstatus sebagai petani penggarap/buruh tani (21,4 persen dari jumlah total responden eksperimen). Fakta ini membuktikan bahwa petani organik sebagian besar adalah petani pemilik lahan dan jumlahnya lebih banyak jika dibandingkan dengan petani konvensional menurut kelompok responden (eksperimen dan kontrol). Jumlah dan persentase responden berdasarkan status petani, selengkapnya disajikan dalam Tabel 4. 
Tabel 4. Jumlah dan Persentase Responden Penelitian Berdasarkan Status Petani di Desa

Ketapang, Tahun 2010

\begin{tabular}{|c|c|c|c|c|c|c|}
\hline \multirow{2}{*}{ Status Petani } & \multicolumn{2}{|c|}{$\begin{array}{c}\text { Petani Organik } \\
n=14\end{array}$} & \multicolumn{2}{|c|}{$\begin{array}{l}\text { Petani Konvensional } \\
\qquad n=65\end{array}$} & \multicolumn{2}{|c|}{$\begin{array}{c}\text { Total Responden } \\
n=79\end{array}$} \\
\hline & $\begin{array}{l}\text { Jumlah } \\
\text { (Orang) }\end{array}$ & $\begin{array}{c}\text { Persentase } \\
(\%)\end{array}$ & $\begin{array}{l}\text { Jumlah } \\
\text { (Orang) }\end{array}$ & $\begin{array}{c}\text { Persentase } \\
(\%)\end{array}$ & $\begin{array}{l}\text { Jumlah } \\
\text { (Orang) }\end{array}$ & $\begin{array}{c}\text { Persentase } \\
(\%)\end{array}$ \\
\hline Pemilik Lahan & 6 & 42,9 & 34 & 52,3 & 40 & 50,6 \\
\hline $\begin{array}{l}\text { Penggarap/Buruh } \\
\text { Tani }\end{array}$ & 3 & 21,4 & 26 & 40 & 29 & 36,7 \\
\hline $\begin{array}{l}\text { Pemilik Lahan dan } \\
\text { Penggarap }\end{array}$ & 5 & 35,7 & 5 & 7,7 & 10 & 12,7 \\
\hline Total & 14 & 100 & 65 & 100 & 79 & 100 \\
\hline
\end{tabular}

Sumber: Data Prime Diolala

\section{Kepemilikan Hewan Ternak}

Kepemilikan hewan ternak ternyata sangat mempengaruhi praktik pertanian organik di Desa Ketapang. Berdasarkan hasil penelitian, terbukti bahwa hampir semua petani organik memiliki hewan ternak. Hanya dua orang petani organik dari empat belas orang responden eksperimen (petani organik) yang tidak memiliki hewan ternak. Selain itu, keberadaan hewan ternak juga sangat membantu petani konvensional dalam memenuhi kebutuhan pupuk kandang sebagai pendukung pupuk kimia sintetik, sehingga dapat mengurangi biaya pemupukan pada lahan pertanian mereka. Para petani konvensional di Desa Ketapang saat ini telah mulai mengurangi penggunaan pupuk kimia sintetik secara perlahan-lahan dengan memanfaatkan pupuk kandang. Persentase jumlah responden eksperimen yang memiliki hewan ternak adalah 85,7 persen dari jumlah total responden eksperimen. Persentase tersebut lebih besar daripada persentase jumlah responden kontrol yang memiliki hewan ternak, yaitu hanya 53,8 persen dari jumlah total responden kontrol. Jumlah dan persentase responden yang memiliki hewan ternak, secara lengkap dapat dilihat pada Tabel 5. Sebagian besar responden dalam penelitian ini memiliki hewan ternak yang berlokasi di pekarangan rumah atau tidak jauh dari rumah mereka. Ada 47 orang responden yang memiliki hewan ternak dengan jenis sebagai berikut: sapi, kambing, kerbau, kelinci, ayam, dan burung merpati. Sementara itu, jumlah responden yang tidak memiliki hewan ternak adalah 32 orang atau 40,5 persen dari jumlah total responden penelitian (Tabel 5).
Tabel 5. Jumlah dan Persentase Responden Penelitian Berdasarkan Jenis Kepemilikan Hewan Temak di Desa Ketapang, Tahun 2010

\begin{tabular}{|l|c|c|c|c|c|c|}
\hline \multirow{2}{*}{ Kepemilikan Ternak } & \multicolumn{2}{|c|}{$\begin{array}{c}\text { Petani Organik } \\
\mathrm{n}=14\end{array}$} & \multicolumn{2}{c|}{$\begin{array}{c}\text { Petani Konvensional } \\
\mathrm{n}=65\end{array}$} & \multicolumn{2}{c|}{$\begin{array}{c}\text { Total Responden } \\
\mathrm{n}=79\end{array}$} \\
\cline { 2 - 7 } & $\begin{array}{c}\text { Jumlah } \\
(\text { Orang) }\end{array}$ & $\begin{array}{c}\text { Persentase } \\
(\%)\end{array}$ & $\begin{array}{c}\text { Jumlah } \\
(\text { Orang) }\end{array}$ & $\begin{array}{c}\text { Persentase } \\
(\%)\end{array}$ & $\begin{array}{c}\text { Jumlah } \\
(\text { Orang) }\end{array}$ & $\begin{array}{c}\text { Persentase } \\
(\%)\end{array}$ \\
\hline Tidak Punya & 2 & 14,3 & 30 & 46,2 & 32 & 40,5 \\
\hline Kelinci & 1 & 7,1 & 1 & 1,5 & 2 & 2,5 \\
\hline Sapi & 1 & 7,1 & 3 & 4,6 & 4 & 5,1 \\
\hline Kambing & 4 & 28,6 & 18 & 27,7 & 22 & 27,8 \\
\hline Ayam & 1 & 7,1 & 8 & 12,3 & 9 & 11,4 \\
\hline Kerbau & 0 & 0 & 3 & 4,6 & 3 & 3,8 \\
\hline Sapi dan Kambing & 4 & 28,6 & 0 & 0 & 4 & 5,1 \\
\hline Kambing dan Ayam & 1 & 7,1 & 1 & 1,5 & 2 & 2,5 \\
\hline $\begin{array}{l}\text { Sapi, Kambing, Ayam, } \\
\text { Burung Merpati }\end{array}$ & 0 & 0 & 1 & 1,5 & 1 & 1,3 \\
\hline Total & $\mathbf{1 4}$ & $\mathbf{1 0 0}$ & $\mathbf{6 5}$ & 100 & 79 & 100 \\
\hline
\end{tabular}

Sumber. Data Primer Diolah

\section{HASIL PENELITIAN DAN PEMBAHASAN}

\section{Pengaruh Praktik Pertanian Organik terhadap Keberlanjutan Ekonomi Petani}

Berdasarkan hasil penelitian, praktik pertanian organik ternyata berpengaruh positif secara signifikan terhadap keberlanjutan ekonomi petani. Hal ini dibuktikan dari analisis finansial usahatani organik dan konvensional, seperti yang ditunjukkan dalam Tabel 6 dan Tabel 7 . Berdasarkan Tabel 6 dan Tabel 7, terlihat bahwa total biaya input produksi rata-rata usahatani organik per 0,24 ha per musim lebih besar daripada usahatani konvensional. Hal ini disebabkan oleh semakin tingginya biaya tenaga kerja dan upah panen setelah petani menjalankan praktik pertanian organik. Dari semua kategori biaya input produksi, biaya input terbesar berada pada biaya tenaga kerja dan upah panen pada kedua sistem usahatani. Meskipun biaya input produksi usahatani organik lebih besar daripada usahatani konvensional, tetapi jumlah penerimaan rata-rata usahatani organik per 0,24 ha per musim ternyata jauh lebih besar dibandingkan usahatani konvensional. Demikian pula dengan keuntungan rata-rata usahatani per 0,24 ha per musim yang jauh lebih besar usahatani organik daripada konvensional.

Analisis Finansial diakhiri dengan menghitung nilai B/C Rasio pada kedua sistem usahatani. Berdasarkan hasil penelitian, didapatkan nilai B/C Rasio usahatani organik sebesar 1,7 sedangkan nilai B/C Rasio usahatani konvensional hanya 0,9 (Tabel 6 dan Tabel 7). Oleh karena itu, dapat disimpulkan bahwa usahatani organik layak secara ekonomi, sedangkan usahatani konvensional tidak layak secara ekonomi karena nilai B/C Rasionya kurang dari 1. Hal ini diperkuat dengan hasil analisis statistik dengan menggunakan uji Paired Samples T-test yang menghasilkan nilai signifikansi sebesar 0,000 dan nilai tersebut kurang dari 0,05 yang artinya ada perbedaan secara signifikan antara keuntungan usahatani sebelum dan sesudah organik, sehingga hipotesis penelitian yang menyatakan bahwa praktik pertanian organik diduga berpengaruh positif secara signifikan terhadap keberlanjutan ekonomi petani, terbukti benar dan diterima. 
Tabel 6. Perbandingan Analisis Biaya, Penerimaan dan Keununngan Rata-atata Usahatani Organik dan Konvensional per 0,24 ha per Musim menunt Kelompok Petani Organil dan Konvensional, Desa Ketapang, Jarra Tengah, Tahun 2010

\begin{tabular}{|c|c|c|}
\hline & $\begin{array}{c}\operatorname{Organik}(R p) \\
n=14\end{array}$ & $\begin{array}{c}\text { Konvensional (Rp) } \\
n=65\end{array}$ \\
\hline Input Produksi: & & \\
\hline 1. Bibit & 44.455 & $28.388,8$ \\
\hline 2. Pupuk $K^{2}$ & $36.465,6$ & $371.937,5$ \\
\hline 3. Pestisida & $3.151,3$ & $51.090,6$ \\
\hline $\begin{array}{l}\text { 4. Tenaga Kerja dan Upah } \\
\text { Panen }\end{array}$ & $2.161 .122,2$ & $1.616 .434,5$ \\
\hline Total Biaỵa Input Produksi & 2.245 .194 & $2.067 .851,5$ \\
\hline Penerimaan Isahatani ${ }^{4}$ & $6.096 .150,6$ & $4.009 .191,4$ \\
\hline Keuntungan & $3.850 .956,5$ & $1.941 .339,9$ \\
\hline BC Rasio & 1,7 & 0,9 \\
\hline
\end{tabular}

Sumber: Data Pfimer Diolah

Keterangan:

${ }^{1}$ Termasulk biaya menggunakan bibit Beras Merah oleh sanu orang petani organik.

'Termasuk biaya menggunakan pupuk kompos dan Bioton oleh satu orang petani organik, setta pupuk KCL dan .PK oléh dua orang petani konvensional.

'Upah panen dihitung $1 / 5$ dari penerimaan usahatani cengan basis hitungan gabah basah (Rp).

${ }^{4}$ Dihitung dari perkalian antara hasil panen dalam bentuk gabah basain (kg) dengan harga jual gabah bassah per kg. yain Rp. 2.700,00 lalu didurangi upal panen.

Tabel 7. Perbandingan Analisis Biaya, Penerimaan dan Ke euntungan Rata-nata Usahatani Sebelum dan Sesudah Organilk per 0,24 ha per Musimm menurut Kelompok Petani Organili, Desa Ketapange, Jawa Tengah, Tahun 2010

\begin{tabular}{|l|c|c|}
\hline & $\begin{array}{c}\text { Sebelum Organik (Rp) } \\
\mathrm{n}=14\end{array}$ & $\begin{array}{c}\text { Sesudah Organik (Rp) } \\
\mathrm{n}=14\end{array}$ \\
\hline $\begin{array}{l}\text { Input Produksi: } \\
\text { 1. Bibit }\end{array}$ 2. Pupuk $^{2}$ & $37.721,1$ & 44.455 \\
3. Pestisida & $393.217,8$ & $36.465,6$ \\
4. Tenaga Kerja dan Upah & 47.463 & $3.151,3$ \\
Panen $^{3}$ & $1.659 .626,9$ & $2.161 .122,2$ \\
\hline Total Biaya Input Produksi $^{2}$ & $2.138 .028,8$ & 2.245 .194 \\
\hline Penerimaan Usahatani & \\
\hline Keuntungan & $4.113 .909,7$ & $6.096 .150,6$ \\
\hline B/C Rasio & $1.975 .880,9$ & $3.850 .956,5$ \\
\hline
\end{tabular}

Sumber. Data Primer Diolah

Keterangan:

${ }^{1}$ Termasuk biaya menggunakan bibit Beras Merah oleh sanu orang petani organik.

'Termasuk biaya menggunakan pupuk kompos dan Bioton oleh satu orang petani organik, serta pupuk SP 36 ,

NPK dan ZA yang digunakan oleh satu orang petani sebelum organik

${ }^{3}$ Upah panen dihitung $1 / 5$ dari penerimaan usahatani dengan basis hitungan gabah basah (Rp)

${ }^{4}$ Dihitung dari perkalian antara hasil panen dalam bentuk gabah basah $(\mathrm{kg})$ dengan harga jual gabah basah per $\mathrm{kg}$, yaim Rp. 2.700,00 lalu dilurangi upah panen.

Pengaruh praktik pertanian organik terhadap keberlanjutan ekonomi petani yang telah terbukti positif, ternyata menjadi alasan utama para petani untuk beralih dari pertanian konvensional menuju pertanian organik. Alasan kedua para petani mau bertani organik selain karena aspek ekonomi, adalah aspek ekologi. Semua responden eksperimen dalam penelitian ini menyatakan bahwa praktik pertanian organik berpengaruh positif terhadap keberlanjutan ekologi. Hal ini dapat dilihat dari perubahan tekstur tanah yang semakin gembur dan tingkat kesuburan tanah yang semakin tinggi setelah bertani organik. Selain itu, kualitas produk pertanian organik ternyata lebih baik daripada kualitas produk pertanian konvensional, misalnya: beras organik terbukti lebih tahan lama dan rasanya lebih enak dengan kandungan nutrisi lebih tinggi daripada beras konvensional. Keuntungan praktik pertanian organik secara ekonomi dan ekologi inilah yang membuat para petani organik masih bertahan untuk terus melanjutkan praktik pertanian organik di Desa Ketapang, meskipun tidak banyak petani yang mengadopsinya. Fakta tersebut diperkuat oleh pernyataan salah satu informan penelitian berinisial Bsr (laki-laki, 61 tahun), sebagai berikut:

"Kami mau bertani organik pada mulanya karena menguntungkan secara ekonomi. Biaya produksi lebih murah, harga jual produknya lebih tinggi. Jadi, ya untung Mas. Selain itu, pertanian organik ini bisa menggemburkan tanah, sehingga tanah lebih subur daripada pas dulu saat saya dan beberapa teman masih menjalankan pertanian non organik. Penggunaan pupuk sintetik yang berlebihan ternyata membuat tanah kering, pecah-pecah dan lama-lama nggak subur lagi. Saya bilangnya pupuk sintetik lo ya, bukan pupuk kimia soalnya semua pupuk, baik organik atau non organik kan mengandung bahan-bahan kimia. Terus, saya bertani organik juga karena alasan kesehatan. Beras organik dan lahan organik kan lebih sehat Mas, soalnya nggak tercemar racun, daripada yang pertanian non organik. Memang susah sih bertani organik itu banyak sekali kendalanya, tapi saya masih mau bertahan karena beberapa keuntungan tadi dan peluang pasar organik masih terbuka lebar ,"

\section{Analisis Kompleksitas Praktik Pertanian Organik dan Konvensional menurut Persepsi Petani}

Praktik pertanian organik secara umum, tidak jauh berbeda dengan praktik pertanian konvensional. Namun, ada beberapa variabel yang menjadi perhatian utama apakah sistem pertanian tersebut dikategorikan sebagai pertanian organik atau bukan, yaitu:

1) Lahan pertanian harus dikonversi dari lahan non organik menjadi organik tanpa tercemar bahan kimia sintetik selama $\geq 3$ tahun.

2) Menggunakan pupuk organik.

3) Menggunakan bibit padi varietas lokal.

4) Pengendalian hama dan penyakit tanaman dengan menggunakan pestisida organik.

5) Lahan dan sumber air irigasi untuk pertanian organik harus dipisahkan dari pertanian konvensional. 
Beberapa variabel di atas merupakan variabel sensitif yang telah banyak disyaratkan dalam pertanian organik dan telah dilaksanakan oleh para petani organik di Desa Ketapang. Sementara itu, praktik pertanian konvensional merupakan kebalikan dari praktik pertanian organik. Jadi, beberapa variabel sensitif dari praktik pertanian konvensional yang dapat dibandingkan tingkat kompleksitasnya dengan praktik pertanian organik, antara lain:

1) Lahan pertanian tidak perlu dikonversi menjadi lahan organik dan tetap diberikan input bahan-bahan kimia sintetik.

2) Menggunakan pupuk kimia sintetik.

3) Menggunakan bibit padi varietas hibrida (bibit unggul).

4) Pengendalian hama dan penyakit tanaman dengan menggunakan pestisida kimia sintetik.

5) Lahan dan sumber air irigasi tidak dipisahkan dari sistem pertanian lainnya.

Praktik pertanian organik harus saling terintegrasi antara satu dengan lainnya selama proses bertani dalam satu musim. Praktik ini dimulai dari penyiapan lahan sebelum padi ditanam hingga pasca panen, yang meliputi:

1) Pembajakan dengan menggunakan kerbau atau traktor yang diikuti dengan penyebaran pupuk organik basah berupa granul (pupuk kandang hasil fermentasi dan penggilingan) atau pupuk hijau berupa daun-daunan yang dibenamkan ke dalam tanah. Pembajakan dengan menggunakan dua ekor kerbau, biasanya membutuhkan waktu kurang lebih dua hari. Setelah tanah dibajak, tanah dibiarkan terdedah tanpa perlakuan agar gembur.

2) Perataan tanah dengan menggunakan kerbau atau traktor. Perataan tanah biasanya membutuhkan dua ekor kerbau dan dapat diselesaikan sekitar satu hari.

3) Pencangkulan tanah yang melibatkan petani secara langsung. Cangkul yang digunakan harus terbebas dari bahan-bahan kimia sintetik. Jika tidak, maka cangkul harus dicuci atau dibersihkan terlebih dahulu sampai steril atau higienis.

4) Penanaman padi atau seringkali disebut "tandur" oleh petani di Desa Ketapang. Penanaman padi ini, melibatkan petani perempuan hingga masa tanam selesai.

5) Pemupukan dengan menggunakan pupuk organik yang terdiri dari: pupuk kandang kering dan pupuk cair (terbuat dari urine hewan ternak atau urine manusia). Pupuk cair disemprotkan ke bagian daun hingga batang tanaman padi sebanyak empat sampai lima kali.

6) Pengendalian hama dan penyakit tanaman dengan menyemprotkan pestisida organik ke bagian daun hingga batang tanaman padi.

7) Penyiangan dan pembersihan galengan. Proses penyiangan (maton) dimanfaatkan oleh petani untuk mendapatkan pupuk hijau tambahan dengan cara membenamkan sisa-sisa rumput atau daun-daunan yang telah dicabuti ke dalam tanah.

8) Pemanenan padi yang mengikutsertakan petani lakilaki dan perempuan. Semua hasil panen dalam bentuk gabah basah harus disimpan ke dalam tempat atau wadah yang terbebas dari bahan kimia sintetik.

9) Penjemuran padi untuk menghasilkan gabah kering yang siap digiling ke tempat penggilingan atau selepan. Jika padi dibawa ke tempat penggilingan, maka gudang tempat penyimpanan padi dan semua lingkungan penggilingan harus terbebas dari bahan kimia sintetik. Oleh karena itu, penyemprotan pestisida sintetik di dalam gudang atau tempat penggilingan, dilarang keras.

10)Penggilingan padi yang dilakukan jika petani ingin menjual hasil panennya dalam bentuk beras.

11)Pengemasan padi dalam bentuk beras yang biasanya dilakukan di sekretariat Paguyuban Petani AlBarokah. Pengemasan ini bertujuan untuk menambah nilai jual beras organik kepada konsumen. Pengemasan juga harus dilakukan secara hati-hati agar tidak tercemar bahan-bahan kimia sintetik.

Semua proses bertani dalam sistem usahatani organik yang telah disebutkan di atas, sebenarnya sama dengan proses bertani dalam sistem usahatani konvensional. Namun, praktik pertanian organik membutuhkan ketelitian dan kerja keras yang lebih besar daripada praktik pertanian konvensional untuk menjaga agar lahan pertanian dan lingkungan sekitar sistem usahatani tersebut, tidak tercemar oleh bahan-bahan kimia sintetik. Selain itu, masa panen pertanian organik juga lebih lama daripada pertanian konvensional. Hal ini terjadi karena menurut penuturan salah satu informan penelitian, yaitu Bapak Msl (laki-laki, 55 tahun), pertanian organik mensyaratkan penggunaan bibit padi varietas lokal yang masa berbuahnya lebih lama daripada bibit padi hibrida. Selisih masa panen antara pertanian organik dengan konvensional adalah lima belas hari dan dalam waktu dua tahun, pertanian organik mampu panen sebanyak lima kali, sedangkan pertanian konvensional dalam waktu dua tahun bisa panen lebih dari lima kali.

Pola tanam dalam sistem pertanian organik sama dengan pola tanam dalam sistem pertanian konvensional. Petani tidak merasakan perbedaan yang nyata mengenai pola tanam antara sebelum dan sesudah bertani organik. Tanaman budidaya yang ditanam sepanjang tahun oleh petani adalah padi sawah, kecuali beberapa petani yang memiliki lahan kering. Petani yang memiliki lahan kering, biasanya menanam tanaman palawija atau kacangkacangan selain padi (Tabel 26). Beberapa tahun yang lalu, ketika musim hujan dan kemarau masih bisa diprediksi, mayoritas petani mulai bercocok tanam pada bulan Maret hingga masa panen tiba pada bulan Juni dan seterusnya. Suatu sistem usahatani konvensional membutuhkan waktu sekitar 105 hari untuk menghasilkan panen padi dalam satu musim. Sistem usahatani organik pada umumnya membutuhkan waktu sekitar 120 hari (15 hari lebih lama) untuk menghasilkan panen padi dalam satu musim. Saat ini, petani sudah tidak mampu memprediksi kapan datangnya musim hujan atau kemarau 
akibat anomali iklim, sehingga mereka mulai bercocok tanam pada bulan apapun. Jadi, tidak ada lagi ketentuan khusus mengenai kapan petani harus mulai bercocok tanam hingga panen.

Analisis kompleksitas praktik pertanian organik dan konvensional menurut persepsi petani dilakukan untuk mengetahui perbandingan tingkat kompleksitas dari kedua praktik pertanian tersebut. Analisis ini diperoleh setelah petani menilai sendiri sampai sejauh mana tingkat kompleksitas masing-masing variabel praktik pertanian 20 organik dan konvensional yang telah disebutkan pada paragraf sebelumnya berdasarkan persepsi mereka. Semua responden sama-sama diminta untuk membandingkan tingkat kompleksitas masing-masing variabel praktik pertanian organik dan konvensional dengan kategori nilai yang telah ditentukan oleh penulis (Tabel 6). Data hasil penilaian tersebut, selanjutnya diolah dan dianalisis dengan menggunakan program SPSS 17 for Windows melalui uji Kolmogorov-Smirnov. Hasil pengolahan dan analisis data kemudian menjadi dasar diterima tidaknya hipotesis kedua dari penelitian ini yang menyatakan bahwa tingkat kompleksitas praktik pertanian organik diduga lebih tinggi secara signifikan daripada praktik pertanian konvensional menurut persepsi petani.

Hipotesis penelitian akan ditolak jika nilai signifikansi semua variabel praktik pertanian yang dinilai oleh petani mayoritas lebih besar dari 0,05 dan nilai rataan (mean) kelima variabel praktik pertanian organik mayoritas lebih kecil daripada nilai rataan (mean) kelima variabel praktik pertanian konvensional. Sebaliknya, hipotesis penelitian akan diterima jika nilai signifikansi semua variabel praktik pertanian yang dinilai oleh petani mayoritas lebih kecil dari 0,05 dan nilai rataan (mean) kelima variabel praktik pertanian organik mayoritas lebih besar daripada nilai rataan (mean) kelima variabel praktik pertanian konvensional. Penjelasan lebih lengkap mengenai hasil analisis kompleksitas praktik pertanian organik dan konvensional menurut persepsi petani, dijelaskan dalam sub bab tersendiri berdasarkan kelompok responden (eksperimen dan kontrol).

\section{Analisis Kompleksitas Praktik Pertanian Organik dan Konvensional menurut Persepsi Kelompok Petani Organik (Responden Eksperimen)}

Gambar 2 berisi informasi mengenai nilai rataan (mean) tingkat kompleksitas masing-masing variabel praktik pertanian organik dan konvensional menurut persepsi kelompok petani organik. Berdasarkan Gambar 2, diketahui bahwa nilai rata-rata tingkat kompleksitas semua variabel praktik pertanian organik (v1-v5) lebih besar daripada nilai rata-rata tingkat kompleksitas semua variabel praktik pertanian konvensional (v1-v5). Hal ini berarti, menurut penilaian kelompok petani organik, praktik pertanian organik dirasakan lebih kompleks atau lebih sulit daripada praktik pertanian konvensional. Namun, keputusan untuk menerima atau menolak hipotesis penelitian masih ditentukan oleh nilai signifikansi tingkat kompleksitas pada masing-masing variabel praktik pertanian (v1-v5). Nilai signifikansi berguna untuk menunjukkan ada tidaknya perbedaan nyata antara tingkat kompleksitas masing-masing variabel praktik pertanian organik dan konvensional secara statistik. Nilai signifikansi tingkat kompleksitas untuk masing-masing variabel praktik pertanian hasil dari perhitungan uji Kolmogorov-Smirnov dengan menggunakan program SPSS 17 for Windows disajikan dalam Tabel 8

Gambar 2. Perbandingan Nilai Rataan (Mean) Tingkat Kompleksitas Variabel Praktlk
Pertanian Organil dan Konvensional menurut Persepsi Kelompok Petani Organik, Desa Ketapang, Jawa Tengah, Tahun 2010

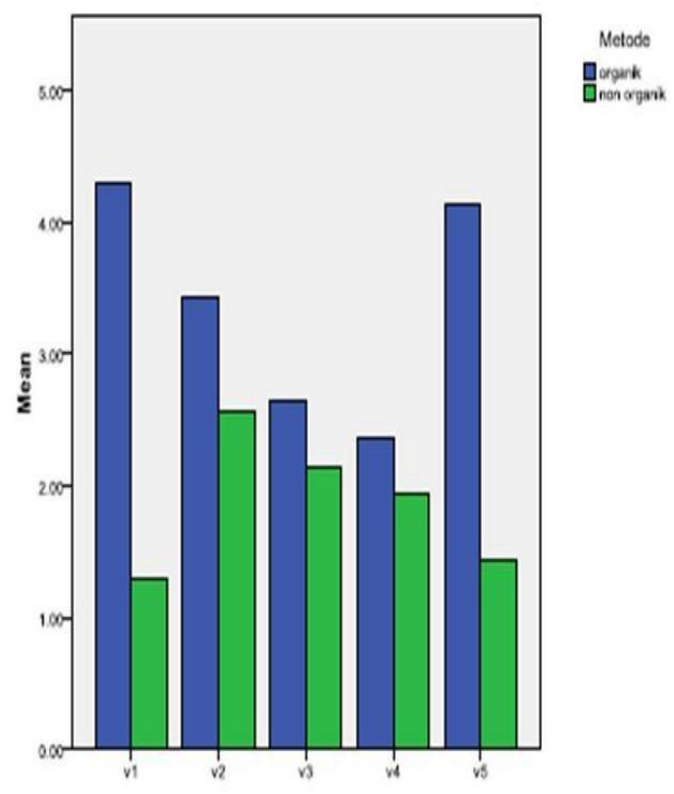

Sumber: Date Primer Diolab

Keterasgas

Variabel Prastek Pertuis Organj (diagram wana biru):

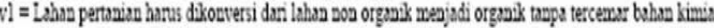
siatetld seinan $\geq 3$ tahto

$v 2=$ Veeggunakan pupuk organi

vì = Nengguaksm bobit pad wrietas loka:

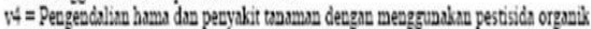

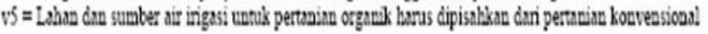

Varibel Praltak Pertonin Konvensiogal (diagux wasa hajou)

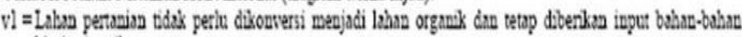
kimis sintetik

v2 $=$ Venggusaka pupulk kimia sictetik

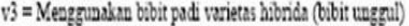

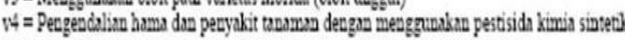

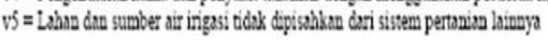

Tabel 8. Nilai Signifikansi Tingkat Kompleksitas Masing-masing Variabel Praktik Pertanian menurut Kelompok Petani Organik, Desa Ketapang, Jawa Tengah, Tahun 2010

\begin{tabular}{|c|c|}
\hline Variabel Praktik Pertanian & $\begin{array}{c}\text { Nilai Signifikansi } \\
\mathrm{n}=14\end{array}$ \\
\hline$v 1$ & 0,000 \\
\hline$v 2$ & 0,334 \\
\hline$v 3$ & 0,905 \\
\hline$v 4$ & 0,905 \\
\hline$v 5$ & 0,000 \\
\hline
\end{tabular}

Sumber: Data Primer Diolah

Berdasarkan Tabel 8, dapat diketahui bahwa variabel 1 (v1) dan variabel 5 (v5) memiliki nilai signifikansi lebih kecil dari 0,05 , yaitu 0,000 . Hal ini berarti, terdapat 
perbedaan nyata antara tingkat kompleksitas praktik pertanian organik dan konvensional dalam hal praktik dan masa konversi lahan dari non organik menjadi organik (variabel 1) serta praktik pemisahan lahan dan sumber irigasi pertanian organik dari pertanian konvensional (variabel 5). Fakta tersebut diperkuat oleh Gambar 2 yang menunjukkan lebih besarnya nilai mean tingkat kompleksitas variabel 1 dan variabel 5 praktik pertanian organik dibandingkan praktik pertanian konvensional. Jadi, dapat disimpulkan bahwa tingkat kompleksitas praktik pertanian organik terbukti lebih tinggi secara signifikan daripada praktik pertanian konvensional menurut persepsi kelompok petani organik berdasarkan variabel 1 dan variabel 5 .

Tingkat kompleksitas untuk variabel praktik pertanian lainnya selain variabel 1 dan variabel 5 (v2-v4), memiliki nilai signifikansi lebih lebih besar dari 0,05 (Tabel 32). Hal ini berarti tidak ada perbedaan tingkat kompleksitas yang signifikan antara praktik pertanian organik dan konvensional berdasarkan variabel 2, variabel 3, dan variabel 4. Padahal, berdasarkan Gambar 2, terlihat jelas adanya perbedaan nilai mean tingkat kompleksitas yang cukup nyata pada variabel 2 hingga variabel 4 antara praktik pertanian organik dan konvensional. Namun, penarikan kesimpulan atas diterima tidaknya hipotesis penelitian tetap dilihat berdasarkan nilai signifikansi. Jadi, dapat disimpulkan bahwa tidak ada perbedaan tingkat kompleksitas secara signifikan antara praktik pertanian organik dan konvensional menurut persepsi kelompok petani organik berdasarkan variabel 2 , variabel 3 , dan variabel 4.

Hasil analisis statistik yang telah dijelaskan pada paragraf di atas, telah memperlihatkan bahwa praktik pertanian organik terbukti lebih kompleks atau lebih sulit secara signifikan daripada praktik pertanian konvensional hanya pada variabel 1 dan variabel 5. Sementara itu, perbandingan tingkat kompleksitas tiga variabel lainnya antara praktik pertanian organik dan konvensional, tidak berbeda secara signifikan. Berdasarkan hal tersebut, maka kesimpulan umum atas hipotesis penelitian kedua yang menyatakan bahwa tingkat kompleksitas praktik pertanian organik diduga lebih tinggi secara signifikan daripada praktik pertanian konvensional menurut persepsi petani, adalah ditolak. Jadi, tidak ada perbedaan tingkat kompleksitas secara signifikan antara praktik pertanian organik dan konvensional menurut persepsi kelompok petani organik.

Penjelasan lebih lanjut mengenai alasan para petani organik (responden eksperimen) menerima dan menolak hipotesis penelitian kedua berdasarkan setiap variabel praktik pertanian, adalah sebagai berikut:

1) Lahan pertanian harus dikonversi dari lahan non organik menjadi organik tanpa tercemar bahan kimia sintetik selama $\geq 3$ tahun (variabel 1) dinilai membutuhkan waktu yang sangat lama dan cenderung lebih sulit dilakukan daripada praktik pengolahan lahan pada pertanian konvensional. Jadi, petani harus sabar menunggu hingga lahan pertanian dan hasil panennya bisa disebut organik. Oleh karena itu, hipotesis kedua dari penelitian ini diterima berdasarkan tingkat kompleksitas variabel 1.
2) Menggunakan pupuk organik (variabel 2) dinilai tidak sulit oleh para petani organik karena mereka sudah terbiasa membuat pupuk organik sendiri dan ketersediaan pupuk organik juga sangat melimpah di lingkungan sekitar mereka. Hal terpenting bagi petani organik adalah ulet dan sabar karena pupuk organik berbeda dengan pupuk kimia sintetik yang sudah siap pakai. Oleh karena itu, petani organik menganggap bahwa praktik menggunakan pupuk organik tidak lebih sulit dari praktik menggunakan pupuk kimia sintetik. Jadi, hipotesis kedua dari penelitian ini ditolak berdasarkan tingkat kompleksitas variabel 2 .

3) Menggunakan bibit padi varietas lokal (variabel 3) dinilai mudah dan tidak ada perbedaan tingkat kompleksitas jika dibandingkan dengan praktik menggunakan bibit padi varietas hibrida pada pertanian konvensional. Hal ini disebabkan karena harga bibit padi varietas lokal hampir sama dengan varietas hibrida. Kalaupun harganya berbeda, selisih harga antara bibit padi varietas lokal dan hibrida tidak besar. Selain itu, secara teknis penanaman bibit padi varietas lokal sama dengan varietas hibrida. Oleh karena itu, hipotesis kedua dari penelitian ini ditolak berdasarkan tingkat kompleksitas variabel 3.

4) Pengendalian hama dan penyakit tanaman dengan menggunakan pestisida organik (variabel 4) ternyata tidak lebih sulit daripada pengendalian hama dan penyakit tanaman dengan menggunakan pestisida kimia sintetik. Menurut petani, penggunaan pestisida baik pada saat sebelum maupun sesudah organik, sangat jarang dilakukan jika tidak ada serangan hama yang menakutkan. Selain itu, cara membuat pestisida organik pun dianggap sederhana oleh petani organik karena mereka sudah terbiasa memanfaatkan sumber daya nabati di sekitar lingkungan. Oleh karena itu, hipotesis kedua dari penelitian ini ditolak berdasarkan tingkat kompleksitas variabel 4.

5) Lahan dan sumber air irigasi untuk pertanian organik harus dipisahkan dari pertanian konvensional (variabel 5) dinilai lebih sulit daripada lahan dan sumber air irigasi untuk pertanian konvensional yang tidak harus dipisahkan dengan sistem pertanian lainnya. Petani mengaku kesulitan untuk menghindari pencemaran bahan kimia sintetik dari lahan maupun sumber air irigasi di sekitar mereka karena terlalu banyak lahanlahan pertanian dan sumber air irigasi untuk pertanian konvensional. Jadi, pertanian organik membutuhkan perlakuan yang sangat hati-hati dan harus terisolasi dari pencemaran bahan-bahan kimia sintetik, sehingga hipotesis kedua dari penelitian ini diterima berdasarkan tingkat kompleksitas variabel 5.

Penolakan atas hipotesis kedua dari penelitian ini yang diuji pada kelompok petani organik diperkuat oleh pernyataan salah satu informan penelitian, seperti di bawah ini:

\footnotetext{
"Menurut saya, praktik pertanian organik tidak sulit kok kalau dibandingkan dengan praktik pertanian yang non organik. Sebenarnya, secara umum praktiknya hampir sama tetapi pertanian organik ini
} 
kan harus terbebas dari bahan-bahan kimia sintetik jadi kita harus memperlakukannya dengan sangat hatihati, mulai dari penggunaan pupuknya, pestisida, bibit, sumber irigasi, dan lainlain. Praktik pertanian organik malah bisa saya katakan jauh lebih mudah daripada non organik karena saya sudah terbiasa berorganik mulai tahun 1998. Selain itu, biaya produksinya juga lebih murah dan menguntungkan secara ekonomis. Cuma, petani-petani di sini saja yang kurang rekoso istilahnya, opo males ngono lo Mas, kurang telaten." (Mst, lakilaki, 43 tahun).

\section{Analisis Kompleksitas Praktik Pertanian Organik dan Konvensional menurut Persepsi Kelompok Petani Konvensional (Responden Kontrol)}

Analisis kompleksitas praktik pertanian organik dan konvensional menurut persepsi kelompok petani konvensional, bertujuan untuk mengetahui sampai sejauh mana tingkat kompleksitas praktik pertanian organik dibandingkan praktik pertanian konvensional menurut persepsi kelompok petani konvensional. Kesimpulan atas diterima atau ditolaknya hipotesis penelitian berdasarkan nilai signifikansi yang merupakan hasil perhitungan statistik dari uji Kolmogorov-Smirnov dengan menggunakan program SPSS 17 for Windows. Selain itu, untuk memperkuat kecenderungan mengenai manakah praktik pertanian yang tingkat kompleksitasnya lebih tinggi, maka penulis juga menyajikan perbandingan nilai mean tingkat kompleksitas masing-masing variabel praktik pertanian organik dan konvensional dalam Gambar 3.

Berdasarkan Gambar 3, dapat diketahui bahwa nilai mean tingkat kompleksitas semua variabel praktik pertanian organik lebih besar daripada praktik pertanian konvensional. Hal ini berarti, tingkat kompleksitas praktik pertanian organik dinilai lebih tinggi daripada praktik pertanian konvensional oleh responden kontrol. Selisih nilai mean terbesar antara praktik pertanian organik dan konvensional, berada pada variabel 1 dan variabel 5. Jadi, variabel 1 dan variabel 5 dianggap oleh petani sebagai variabel praktik pertanian organik yang tingkat kompleksitasnya paling tinggi dibandingkan variabel lainnya. Meskipun demikian, fakta ini masih belum dapat membuktikan kebenaran hipotesis penelitian kedua karena harus melihat nilai signifikansi tingkat kompleksitas masing-masing variabel praktik pertanian terlebih dahulu, seperti yang tercantum di dalam Tabel 9.
Gambar 3. Perbandingan Nilai Rataan (Mean) Tingkat Kompleksitas Variabel Praltik Pertanian Organik dan Konvensional menurut Persepsi Kelompok Petani Konvensional, Desa Ketapang, Jawa Tengah, Tahun 2010
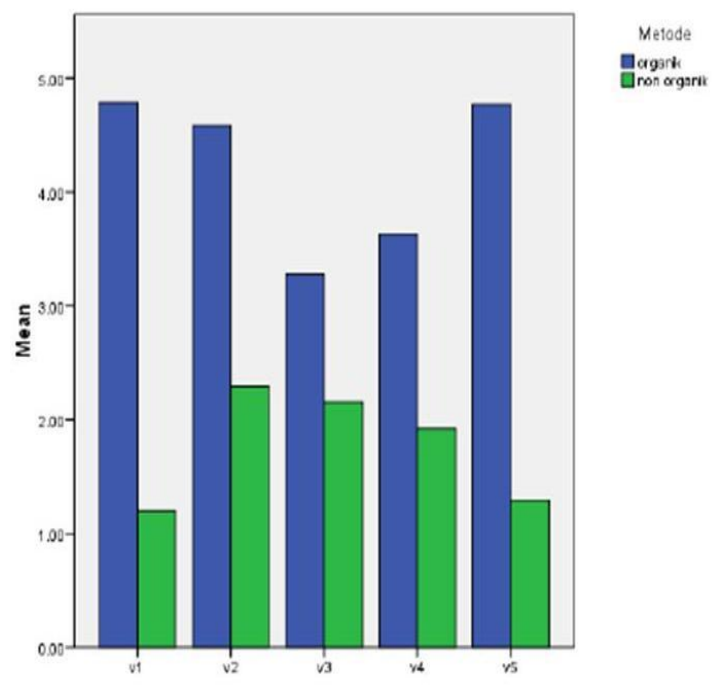

Sumber. Data Primer Diolab

Keterangan:

Variabel Praktik Pertanian Organik (diagram warna biru):

$\mathrm{vl}=$ Lahan pertauian harus dikouversi dari lahan non organik menjadi organik taupa tercemar bahan kimia sinterk selama $\geq 3$ tahum
ting

$2=$ Meagguaskan pupuk organik

$3=$ Mengguaakan bibit padi varetas lokal

$14=$ Pergendalian bama dan peryakit tanaman dengan menggunakan pestisida organil

v $5=$ Laban dan sumber air irgasi unnik pertanian organik harus dipisalksa dari pertanian kouvensional

Variabel Praktrik Pertanian Kontensional (diagram warna hijau):

$\mathrm{l}=$ Lahan pertanian tidak perlu dikocversi meajadi lajan organik dan tetap diberikan input bajan-bahan Liman pertanis
kimia sintedik

v2 $=$ Menggurakan pupuk kimia sinterik

v3 = Menggurakan bibit padi varietas hibrida (oibit unggul)

vi = Pengendalian hama dan peryakit tanaman dengan menggunakan pestisida kimia sineetil

v $S=$ Lahan dan sumber air irgasi tidak dipissibkan dari sistem pertanian laimaya

Tabel9. Nilai Siguifikansi Tingkat Kompleksitas Masing-masing Variabel Praktik Pertanian menurut Kelompok Petani Konvensional, Desa Ketapang, Jawa Tengah, Tahun 2010

\begin{tabular}{|c|c|}
\hline Variabel Praktik Pertanian & $\begin{array}{c}\text { Nilai Signifikansi } \\
n=14\end{array}$ \\
\hline$v 1$ & 0,000 \\
\hline$v 2$ & 0,000 \\
\hline$v 3$ & 0,000 \\
\hline$v 4$ & 0,000 \\
\hline$v 5$ & 0,000 \\
\hline
\end{tabular}

Sumber: Data Primer Diolah

Nilai signifikansi tingkat kompleksitas semua variabel praktik pertanian seperti yang ditampilkan di dalam Tabel 9 adalah sama, yaitu 0,000 dan nilai ini kurang dari 0,05. Berdasarkan nilai signifikansi tersebut, maka dapat dianalisis bahwa terdapat perbedaan tingkat kompleksitas yang signifikan antara praktik pertanian organik dan konvensional menurut persepsi petani konvensional. Hasil analisis ini diperkuat oleh perbedaan nyata nilai mean tingkat kompleksitas antara masing-masing variabel praktik pertanian organik dan konvensional (Gambar 3). Nilai mean tingkat kompleksitas semua variabel praktik pertanian organik lebih tinggi daripada semua variabel praktik pertanian konvensional. Setelah mengetahui hasil analisis statistik di atas, maka kesimpulan umum atas hipotesis kedua dari penelitian ini yang menyatakan 
bahwa tingkat kompleksitas praktik pertanian organik diduga lebih tinggi secara signifikan daripada praktik pertanian konvensional menurut persepsi petani, adalah diterima. Jadi, sudah jelas terbukti bahwa tingkat kompleksitas praktik pertanian organik lebih tinggi secara signifikan daripada praktik pertanian konvensional menurut persepsi kelompok petani konvensional.

Penjelasan lebih lanjut mengenai alasan para petani konvensional (responden kontrol) menerima hipotesis penelitian kedua berdasarkan setiap variabel praktik pertanian, adalah sebagai berikut:

1) Lahan pertanian harus dikonversi dari lahan non organik menjadi organik tanpa tercemar bahan kimia sintetik selama $\geq 3$ tahun (variabel 1) dinilai membutuhkan waktu yang sangat lama dan cenderung lebih sulit dilakukan daripada praktik pengolahan lahan pada pertanian konvensional. Jadi, petani harus sabar menunggu hingga lahan pertanian dan hasil panennya bisa disebut organik. Sebaliknya, praktik pertanian konvensional tidak mensyaratkan adanya perlakuan terhadap lahan seperti ini. Oleh karena itu, hipotesis kedua dari penelitian ini diterima berdasarkan tingkat kompleksitas variabel 1.

2) Menggunakan pupuk organik (variabel 2) dinilai oleh para petani konvensional lebih sulit daripada menggunakan pupuk kimia sintetik. Pupuk organik yang biasanya digunakan di dalam pertanian organik, adalah: pupuk kandang, pupuk cair, pupuk kompos dan pupuk hijau. Petani konvensional merasa kesulitan untuk membuat pupuk organik yang membutuhkan waktu tertentu agar bisa siap digunakan ke lahan. Selain itu, pertanian organik juga membutuhkan pasokan pupuk organik yang tidak sedikit, yaitu sekitar 2,5 ton untuk satu hektar lahan pertanian. Jumlah kebutuhan pupuk organik ini sepuluh kali lipat lebih banyak daripada kebutuhan pupuk kimia sintetik pada pertanian konvensional. Oleh karena itu, transportasi pupuk organik menuju sawah petani sangat sulit dilakukan akibat terlalu beratnya pupuk yang harus diangkut dan sulitnya akses jalan menuju sawah (jalan becek, sempit dan jauh). Jadi, hipotesis kedua dari penelitian ini diterima berdasarkan tingkat kompleksitas variabel 2.

3) Menggunakan bibit padi varietas lokal (variabel 3) sebenarnya mudah dan tidak ada perbedaan tingkat kompleksitas jika dibandingkan dengan praktik menggunakan bibit padi varietas hibrida pada pertanian konvensional. Namun, menurut petani konvensional, penggunaan bibit padi varietas lokal lebih sulit daripada varietas hibrida karena harga bibit padi varietas lokal lebih mahal dibandingkan dengan varietas hibrida. Harga satu kilogram bibit padi varietas lokal bisa mencapai Rp. 6.000,00, sedangkan harga bibit padi varietas hibrida per kilogramnya adalah Rp. 5.000,00. Oleh karena itu, hipotesis kedua dari penelitian ini diterima berdasarkan tingkat kompleksitas variabel 3.

4) Pengendalian hama dan penyakit tanaman dengan menggunakan pestisida organik (variabel 4) ternyata lebih sulit daripada pengendalian hama dan penyakit tanaman dengan menggunakan pestisida kimia sintetik. Menurut petani konvensional, dibutuhkan kesabaran dan keuletan dalam membuat pestisida organik yang memanfaatkan sumber daya nabati di sekitar lingkungan. Petani konvensional lebih memilih menggunakan pestisida kimia sintetik yang sudah siap pakai, lebih praktis, dan jumlah pemakaiannya pun tidak banyak dalam satu musim. Oleh karena itu, hipotesis kedua dari penelitian ini diterima berdasarkan tingkat kompleksitas variabel 4.

5) Lahan dan sumber air irigasi untuk pertanian organik harus dipisahkan dari pertanian konvensional (variabel 5) dinilai lebih sulit daripada lahan dan sumber air irigasi untuk pertanian konvensional yang tidak harus dipisahkan dengan sistem pertanian lainnya. Petani mengaku kesulitan untuk menghindari pencemaran bahan kimia sintetik dari lahan maupun sumber air irigasi di sekitar mereka karena terlalu banyak lahanlahan pertanian konvensional. Hal ini akan lebih sulit lagi jika jarak sumber air irigasi sangat jauh dari sawah petani. Jadi, pertanian organik membutuhkan perlakuan yang sangat hati-hati dan harus terisolasi dari pencemaran bahan-bahan kimia sintetik, sehingga hipotesis kedua dari penelitian ini diterima berdasarkan tingkat kompleksitas variabel 5.

Kebenaran atas hipotesis kedua dari penelitian ini, diperkuat oleh pernyataan salah satu responden penelitian, seperti di bawah ini:
"Saya nggak bertani organik soalnya lebih susah dibandingkan pertanian yang biasa. Bertani organik itu butuh tenaga lebih besar. Saya sudah ndak ada tenaga untuk ngangkut pupuk rabuk ke sawah yang kadang jalannya becek, mboten saget dilewati kendaraan niku lo. Dadi ngge males Mas kulo." (Suy, perempuan, 55 tahun).

\section{Analisis Keberlanjutan Praktik Pertanian Organik di Kalangan Petani}

Pengaruh positif praktik pertanian organik terhadap keberlanjutan ekonomi petani dan besarnya potensi sumber daya alam yang mendukung praktik pertanian organik di Desa Ketapang, seharusnya bisa membuat pertanian organik lebih berkembang di kalangan petani. Namun, tidak demikian kenyataannya. Praktik pertanian organik justru cenderung dihindari oleh para petani di Desa Ketapang. Hal ini terlihat dari lebih banyaknya jumlah petani konvensional daripada jumlah petani organik di Desa ini. Perbandingan jumlah responden kontrol dengan responden eksperimen yang cukup jauh (65:14) dalam penelitian ini sudah membuktikan bahwa praktik pertanian organik kurang berkembang. Alasan utama mengapa praktik pertanian organik tidak banyak diadopsi oleh petani di Desa Ketapang, adalah karena praktik pertanian organik tingkat kompleksitasnya lebih tinggi daripada praktik pertanian konvensional menurut persepsi petani khususnya kelompok petani konvensional.

Faktor lain yang kemungkinan besar mempengaruhi pengambilan keputusan para petani untuk mengadopsi praktik pertanian organik atau tidak adalah karakteristik 
sosial ekonomi petani. Karakteristik sosial ekonomi petani merupakan variabel anteseden dalam penelitian ini yang sudah melekat pada diri petani sebelum pertanian organik mulai diperkenalkan di Desa Ketapang. Karakteristik sosial ekonomi petani yang dianalisis dalam penelitian ini, meliputi: tingkat pendidikan, status petani dan kepemilikan ternak. Berdasarkan Tabel 3, diketahui bahwa persentase jumlah petani organik yang memiliki tingkat pendidikan sedang hingga tinggi (lulus SMP/sederajat hingga sarjana) lebih besar daripada petani konvensional. Ada 42,8 persen petani organik dengan tingkat pendidikan lulus SMP/sederajat hingga sarjana dari jumlah total petani organik yang menjadi responden eksperimen penelitian ini, yaitu sebanyak empat belas orang. Sementara itu, persentase jumlah petani konvensional dengan tingkat pendidikan lulus SMP/sederajat hingga sarjana hanya 16,9 persen dari jumlah total petani konvensional yang menjadi responden kontrol penelitian ini, yaitu sebanyak 65 orang.

Lebih tingginya persentase jumlah petani organik yang memiliki tingkat pendidikan sedang hingga tinggi dibandingkan petani konvensional, menjadi bukti nyata pengaruh tingkat pendidikan terhadap proses pengambilan keputusan atas praktik pertanian organik. Petani yang berpendidikan lebih tinggi dibandingkan petani lainnya, cenderung lebih mudah mengadopsi suatu inovasi seperti praktik pertanian organik. Petani konvensional masih tetap tidak mau mengadopsi pertanian organik karena tingkat pendidikan mereka lebih rendah dibandingkan kelompok petani organik, sehingga daya abstraksi mereka atas manfaat dan masa depan pertanian organik, baik untuk diri mereka sendiri maupun untuk lingkungan, sangat kurang. Hal ini berbeda dengan daya abstraksi atau pola pikir para petani organik yang lebih tinggi dan mampu berpikir secara jangka panjang mengenai manfaaat pertanian organik dari sisi ekonomi maupun ekologi. Oleh karena itu, para petani organik mengambil keputusan untuk mengadopsi praktik pertanian organik secara berkelanjutan.

Status petani adalah status kepemilikan petani terhadap lahan pertanian. Berdasarkan hasil penelitian, terdapat tiga jenis status petani atas kepemilikan lahan pertanian. Berdasarkan hasil penelitian, terdapat tiga jenis status petani atas kepemilikan lahan pertanian, yaitu: petani pemilik lahan, petani penggarap atau buruh tani dan petani berstatus ganda (pemilik dan penggarap). Berdasarkan Tabel 4, ada 21,4 persen petani organik yang berstatus sebagai petani penggarap, sehingga 78,6 persen sisanya dari jumlah total responden eksperimen adalah petani organik yang memiliki lahan sendiri. Hal ini berbeda dengan persentase jumlah petani konvensional yang berstatus sebagai petani penggarap, yaitu sebesar 40 persen, sehingga ada 60 persen petani konvensional yang memiliki lahan pertanian sendiri dari jumlah total responden kontrol.

Persentase kepemilikan lahan pertanian yang lebih tinggi pada kelompok petani organik daripada kelompok petani konvensional, menjadi salah satu faktor yang berpengaruh terhadap tingkat adopsi pertanian organik. Petani pemilik lahan cenderung lebih mudah mengadopsi pertanian organik dibandingkan petani penggarap karena resiko atas kegagalan atau periode panen yang lebih lama pada usahatani, bisa ditanggung sendiri tanpa merugikan pihak lain. Sebaliknya, petani penggarap jarang mau mengambil resiko atas kegagalan usahatani atau jarang mau bekerja keras mengkonversi lahan non organik menjadi organik karena merasa lahan pertanian tersebut bukan miliknya. Petani penggarap sebagian besar mengejar target panen yang diberikan oleh pemilik lahan. Mereka akan berusaha semaksimal mungkin untuk dapat menghasilkan panen sebanyak-banyaknya dalam waktu sesingkat-singkatnya. Sehubungan dengan hal tersebut, maka salah satu cara termudah yang bisa dilakukan oleh petani penggarap adalah bertani konvensional, karena sistem pertanian organik membutuhkan waktu panen lebih lama dan tingkat produktivitasnya pun lebih rendah daripada sistem pertanian konvensional, apalagi pada masa-masa awal bertani organik.

Praktik pertanian organik yang mensyaratkan penggunaan pupuk organik, seperti pupuk kandang dan pupuk cair dari urine hewan ternak, membuat keberadaan hewan ternak di lingkungan petani menjadi sangat penting. Oleh karena itu, tingkat kepemilikan ternak di kalangan petani perlu dianalisis karena berpengaruh terhadap ketersediaan pupuk organik, sehingga berpengaruh pula terhadap pengambilan keputusan petani untuk mengadopsi pertanian organik atau tidak. Berdasarkan hasil penelitian, terdapat 14,3 persen petani organik yang tidak mempunyai hewan ternak dan berarti ada 85,7 persen petani organik yang memiliki hewan ternak dari jumlah total responden eksperimen (Tabel 5). Sebagai perbandingan, persentase jumlah petani konvensional yang tidak memiliki hewan ternak adalah sebesar 46,2 persen dari jumlah total responden kontrol. Jadi, ada 53,8 persen petani konvensional yang memiliki hewan ternak dari jumlah total responden kontrol dan persentase tersebut, lebih rendah daripada persentase jumlah petani organik yang memiliki hewan ternak (Tabel 5).

Persentase kepemilikan hewan ternak yang lebih tinggi pada kelompok petani organik daripada kelompok petani konvensional, mempengaruhi tingkat adopsi petani terhadap praktik pertanian organik. Para petani organik tidak ragu dalam mengadopsi pertanian organik karena mereka memiliki ketersediaan pupuk kandang yang lebih besar daripada petani konvensional berdasarkan tingkat kepemilikan ternak. Kelompok petani konvensional seringkali masih ragu apakah akan mengadopsi praktik pertanian organik atau tidak, karena mereka tidak yakin dapat menyediakan pupuk kandang dan pupuk cair sendiri dalam jumlah yang cukup besar untuk kebutuhan lahan pertanian mereka. Oleh karena itu, hingga saat ini belum banyak petani konvensional yang mengadopsi pertanian organik secara penuh di Desa Ketapang. Fakta mengenai pengaruh kepemilikan hewan ternak terhadap proses pengambilan keputusan bertani organik di kalangan petani, diperkuat oleh pernyataan salah satu responden penelitian, sebagai berikut: "Saya belum berorganik ya karena nggak punya pupuk kandang dan nggak punya ternak juga. Jadi, mau gimana lagi." (Mur, perempuan, 70 tahun).

Penjelasan semua paragraf sebelumnya mengenai faktorfaktor pengaruh atau penyebab mengapa banyak petani 
belum mengadopsi pertanian organik, ternyata sesuai dengan hipotesis pengarah penelitian ini yang menyatakan bahwa praktik pertanian organik tidak banyak diadopsi oleh para petani karena diduga memiliki tingkat kompleksitas yang lebih tinggi dibandingkan praktik pertanian konvensional dan dipengaruhi oleh karakteristik sosial ekonomi petani. Hipotesis pengarah tersebut, terus berkembang selama penelitian berlangsung secara kualitatif dan penulis menemukan beberapa alasan lain yang menyebabkan petani tidak banyak mengadopsi praktik pertanian organik di Desa Ketapang, seperti yang dijelaskan sebagai berikut:

1) Pola pikir petani yang masih pragmatis dan menganggap praktik pertanian organik lebih sulit daripada praktik pertanian konvensional. Padahal, mereka belum mencoba praktik pertanian organik terlebih dahulu. Para petani sudah terbiasa bertani secara instan melalui pertanian konvensional dan tidak mau bersusah payah untuk bertani organik, sehingga ketergantungan mereka masih tinggi terhadap bantuan pemerintah, khususnya subsidi pupuk kimia sintetik. Selain itu, rendahnya kesadaran para petani terhadap kelestarian lingkungan juga sangat menghambat perkembangan pertanian organik di Desa Ketapang. Salah satu informan penelitian, yaitu Bapak Msl (lakilaki, 55 tahun) menambahkan:

"Ya itulah susahnya mengajak para
petani untuk berorganik, padahal kita
sudah berusaha keras. Al-Barokah juga
sudah mempunyai beberapa fasilitas yang
mendukung, tapi tetap saja tidak banyak
petani yang mau berorganik. Pola pikir
mereka masih belum berubah dan ndak
mau rekoso karena terbiasa manja atau
serba instan ketika revolusi hijau mulai
masuk hingga saat ini. Mereka tidak mikir
masa depan untuk anak cucu kita yang
juga ingin menikmati kondisi lahan
pertanian yang baik. Saya bertani organik
ini, karena jihad agar lingkungan tetap
lestari, kesehatan tetap terjaga, dan anak
cucu kita masih dapat menikmati
kekayaan sumber daya alam ini dengan
layak."

2) Petani tidak puas jika hanya menggunakan pupuk organik karena warna hijau daun tanaman padi kurang terlihat. Oleh karena itu, banyak petani yang enggan meninggalkan pertanian konvensional dan terus memupuk tanaman padinya dengan pupuk kimia sintetik untuk merangsang pertumbuhan tanaman padi agar warna hijau daunnya terlihat jelas. Hal ini seperti yang diungkapkan oleh salah satu responden penelitian sebagai berikut:

"Saya itu yo mau lo Mas sebenarnya
bertani organik karena memang sudah
terbukti bagus hasil panennya dan
kesuburan tanah tetap terjaga, tapi istri
saya katanya masih belum puas sama
ijonya daun padi. Jadi, kita sampai saat ini
masih semi organik. Kalau cuma dipupuk
organik, warna daun padinya kurang ijo, dadi yo kurang lego ndeloke." (Myd, lakilaki, 44 tahun).

3) Praktik pertanian organik tidak menjamin bebas hama. Petani tidak mau berspekulasi untuk mengadopsi praktik pertanian organik yang secara teknis lebih sulit, karena tidak ada jaminan bebas hama, khususnya hama tikus yang dianggap paling berbahaya. Alasan ini diperkuat oleh kesaksian salah satu responden sebagai berikut:
"Para petani di sini tidak mau bertani organik karena mereka mikir hama itu tetap ada, apalagi tikus yang paling ditakuti warga. Jadi, sama saja, mau bertani organik atau tidak, serangan hama tetap ada dan nggak ada jaminan bebas hama kalau berorganik. Daripada sudah susah-susah bertani organik yang butuh perjuangan lebih tinggi tapi masih saja dirusak tikus, ya mendingan nggak usah sekalian!” (Zuh, laki-laki 36 tahun).

4) Penggunaan pupuk organik lebih sulit daripada pupuk kimia sintetik. Petani banyak yang mengeluh mengenai sulitnya proses pengangkutan pupuk organik ke lahan pertanian, karena pertanian organik membutuhkan asupan pupuk organik yang sangat banyak. Sementara itu, akses tranportasi menuju pematang sawah sulit dijangkau petani dengan kondisi jalan yang buruk (becek, licin). Proses pembuatan pupuk organik juga membutuhkan keuletan dan waktu tertentu, sehingga tidak jarang petani yang lebih memilih menggunakan pupuk kimia sintetik. Alasan ini diperkuat oleh pernyataan salah satu responden penelitian sebagai berikut:
"Saya belum bertani organik soale gak kuat Mas tenagane gawe ngangkut rabuk kandang nang sawah terus belum lagi kalo jalanan menuju sawah becek atau rusak. Jadi, jalan di sepanjang pematang itu gak bisa dilewati sepeda utowo kendaraan liyane, jauh lo Mas!” (Sum, perempuan, 55 tahun).

5) Sebagian petani tidak memiliki pasokan pupuk kandang. Banyak petani konvensional yang masih belum mau bertani organik karena tidak mempunyai hewan ternak di sekitar rumah mereka, sehingga tidak ada persediaan pupuk kandang. Hal ini seperti yang diungkapkan oleh salah satu responden penelitian sebagai berikut: "Saya belum berorganik ya karena nggak punya pupuk kandang dan nggak punya ternak juga. Jadi, mau gimana lagi.” (Mur, perempuan, 70 tahun).

6) Banyak petani di Desa Ketapang yang berstatus sebagai buruh tani. Tugas buruh tani adalah menggarap lahan pertanian milik orang lain dengan target hasil panen yang maksimal dalam waktu sesingkat-singkatnya. Masa panen pada pertanian organik lebih lama daripada pertanian konvensional. Hal inilah yang menghambat buruh tani untuk bisa mendapatkan hasil panen maksimal dalam waktu singkat, karena mereka harus memenuhi target dari 
petani pemilik lahan setiap musim. Pernyataan yang sama diutarakan oleh salah satu responden penelitian, sebagai berikut:

"Kebanyakan petani di sini itu kan buruh
tani Mas, dan kita harus memenuhi target
panen dari pemilik lahan. Kalau bisa,
panen secepatnya dengan hasil sebanyak-
banyaknya, jadi nggak rugi. Kalau kita
berorganik kan lebih lama panennya dan
hasil panennya juga belum tentu sebanyak
pertanian yang non organik." (Muh, laki-
laki, 40 tahun).

7) Sumber air irigasi jauh dari lahan pertanian dan kemungkinan besar sudah tercemar oleh air irigasi pada lahan pertanian konvensional lainnya. Petani masih kesulitan memisahkan sumber air irigasi untuk pertanian organik karena banyaknya lahan pertanian konvensional di sekitarnya. Jadi, kemungkinan besar air irigasi tercemar oleh bahan-bahan kimia sintetik dari lahan pertanian konvensional milik tetangga. Salah satu responden penelitian menambahkan:

"Sumber irigasi jauh dari sawah kita jadi
nggak mungkin berorganik. Sementara
kalau mau berorganik, segala sesuatunya
kan harus terjamin, seperti ketersediaan
air bersih untuk irigasi. Nah, kalau kayak
gini, misalnya kekurangan air atau airnya
tercemar bahan kimia dari lahan,
tetangga, gimana bisa berorganik Mas."
(Mjh, laki-laki, 58 tahun).

8) Hasil panen pertanian organik jumlahnya lebih sedikit dan kurang memuaskan pada masa awal bertani organik. Banyak responden kontrol yang mengaku tidak sabar menunggu hasil panen maksimal dari pertanian organik. Padahal, tingkat produktivitas lahan organik akan kembali normal seperti lahan konvensional pada umumnya setelah tiga tahun atau lebih. Kenyataan inilah yang membuat para petani tidak mau mengadopsi pertanian organik. Para petani hanya mau memikirkan bagaimana cara mendapatkan hasil panen yang banyak dalam waktu singkat, tanpa melalui sebuah proses panjang. Salah satu responden penelitian menyatakan keberatan hatinya untuk bertani organik, seperti kutipan lisan berikut ini: "Saya malas bertani organik soalnya hasil panennya sedikit, jadi kurang memuaskan. Padahal, saya butuh panen cepat dan banyak untuk memenuhi kebutuhan sehari-hari." (Roh, perempuan, 53 tahun).

Fakta mengenai tidak banyaknya petani yang menjalankan praktik pertanian organik di Desa Ketapang beserta alasannya, secara otomatis sudah membuktikan bahwa keberlanjutan praktik pertanian organik di kalangan petani masih rendah berdasarkan tingkat kompleksitas atau tingkat adaptasinya. Praktik pertanian organik dianggap kurang adaptable atau kurang adaptif oleh sebagian besar petani di Desa Ketapang. Padahal, berdasarkan analisis ekonomi dan potensi sumber daya alam di Desa Ketapang, praktik pertanian organik sebenarnya mempunyai prospek yang menjanjikan dalam jangka panjang. Oleh karena itu, perjuangan untuk mengajak para petani beralih dari pertanian konvensional menuju ke pertanian organik harus terus dilakukan demi tercapainya pembangunan pertanian yang berkelanjutan.

\section{PENUTUP}

\section{Kesimpulan}

Praktik pertanian organik terbukti berpengaruh positif terhadap keberlanjutan ekonomi petani berdasarkan hasil analisis finansial usahatani dan analisis statistik menggunakan uji Paired Samples T-test. Hasil analisis finansial usahatani menunjukkan nilai $B / C$ Rasio usahatani organik sebesar 1,7 sedangkan nilai B/C Rasio usahatani konvensional hanya 0,9. Nilai signifikansi hasil uji Paired Samples T-test terhadap keuntungan rata-rata usahatani sebelum dan sesudah organik per 0,24 ha per musim adalah 0,000 dan nilai tersebut lebih kecil dari 0,05. Jadi, hipotesis penelitian pertama yang menyatakan bahwa praktik pertanian organik diduga berpengaruh positif secara signifikan terhadap keberlanjutan ekonomi petani terbukti benar dan diterima.

Analisis kompleksitas praktik pertanian organik dan konvensional memperlihatkan adanya perbedaan yang signifikan antara tingkat kompleksitas praktik pertanian organik dan konvensional menurut persepsi kelompok petani konvensional, sehingga hipotesis penelitian kedua yang menyatakan: tingkat kompleksitas praktik pertanian organik diduga lebih tinggi secara signifikan daripada praktik pertanian konvensional menurut persepsi petani, terbukti benar dan diterima berdasarkan persepsi kelompok petani konvensional. Sementara itu, hipotesis tersebut tidak berlaku untuk kelompok petani organik karena nilai signifikansi sebagian besar variabel praktik pertanian lebih besar dari 0,05. Hanya ada dua variabel praktik pertanian organik yang menunjukkan perbedaan tingkat kompleksitas secara signifikan dengan praktik pertanian konvensional. Variabel tersebut adalah: praktik mengkonversi lahan dari non organik menjadi organik selama lebih dari tiga tahun; dan praktik memisahkan lahan serta sumber irigasi pertanian organik dari sistem pertanian konvensional.

Keberlanjutan praktik pertanian organik di kalangan petani masih rendah berdasarkan fakta mengenai banyaknya petani yang masih belum mengadopsi praktik pertanian organik dan hasil analisis kompleksitas atau tingkat adaptasi praktiknya. Sebuah sistem pertanian bisa dikatakan berkelanjutan jika telah memenuhi semua kriteria pertanian berkelanjutan dan salah satunya adalah adaptable. Praktik pertanian organik masih belum memenuhi syarat adaptable menurut persepsi petani berdasarkan hasil penelitian ini. Meskipun demikian, masih terdapat kemungkinan lain mengapa praktik pertanian organik belum banyak diadopsi oleh petani, bukan hanya karena tingkat kompleksitas praktik pertanian organik atau faktor-faktor penyebab yang telah dibahas dalam penelitian ini. Kelemahan penelitian ini adalah tidak menganalisis hubungan antara karakteristik sosial ekonomi petani dengan proses pengambilan keputusan adopsi atas praktik pertanian organik melalui uji statistik. Penulis hanya menganalisis hubungan tersebut berdasarkan persentase jumlah petani menurut karakteristik sosial ekonominya, sehingga kajian kurang 
mendalam. Selain itu, ada beberapa variabel sosiologis, seperti: pengetahuan dan pengalaman bertani, keaktifan petani dalam kelompok tani, dan lain-lain yang mungkin berpengaruh terhadap proses adopsi inovasi tetapi tidak diteliti oleh penulis.

\section{Saran}

Beberapa saran yang dapat direkomendasikan oleh penulis terkait penelitian ini, antara lain:

1) Perlu diadakan penelitian lebih lanjut mengenai analisis keberlanjutan praktik pertanian organik di kalangan petani selain dilihat dari aspek ekonomi dan tingkat kompleksitas praktik pertanian organik, dengan kasus wilayah pertanian lainnya di dataran rendah.

2) Memperkuat jaringan dan kerjasama antara petani dengan pengusaha, petani dengan pemerintah, dan Lembaga Swadaya Masyarakat (LSM) dengan petani. Hubungan ini akan sangat membantu perkembangan pertanian organik.

3) Meningkatkan akses pasar petani dan memperkuat sistem kontrol internal untuk menjamin keorganikan sistem usahatani yang dijalankan. Para petani organik yang tergabung dalam Paguyuban Petani Al-Barokah dapat menerapkan Participatory Guarantee System (PGS). PGS merupakan sistem sertifikasi yang menekankan partisipasi para pemangku kepentingan. Pada pola PGS, keseluruhan pemangku kepentingan yang terdiri dari: produsen, kelompok tani, konsumen, pendamping, Lembaga Swadaya Masyarakat (LSM), dan distributor terlibat secara aktif untuk membangun dan memberdayakan diri dalam proses produksi, pemasaran atau distribusi sesuai sistem pangan organik. Keikutsertaan aktif dari sejumlah pihak yang berkepentingan akan berdampak pada proses pemberdayaan dan adanya tanggung jawab dari seluruh komponen yang terlibat di dalam sistem penjaminan partisipatoris (PGS).

4) Sarana dan prasarana yang mendukung pertanian organik di Desa Ketapang, seperti alat penggiling pupuk organik atau granul dan lain-lain hendaknya dimanfaatkan serta dirawat lebih maksimal secara berkelompok.

5) Solusi atas kendala utama dalam praktik pertanian organik di Desa Ketapang, misalnya transportasi pupuk organik menuju lahan pertanian, sebaiknya mulai dibicarakan di tingkat kelompok. Petani sangat mengharapkan kerjasama yang kuat dalam bertani organik mengingat tingkat kompleksitasnya yang cukup tinggi dibandingkan praktik pertanian konvensional.

6) Pola pikir petani yang masih pragmatis terhadap pertanian organik perlu segera diubah dengan frekuensi penyuluhan pertanian yang lebih intensif. Selain itu, para petani sebaiknya diajak untuk lebih bersabar dalam melewati masa konversi lahan non organik menjadi organik yang membutuhkan waktu relatif lama. Usaha meyakinkan petani untuk bertani organik, bisa dilakukan melalui demonstrasi lahan atau demonstrasi hasil dan bersama-sama merencanakan strategi, agar fasilitas irigasi untuk pertanian organik yang higienis dapat dinikmati secara bersama oleh petani.

7) Kegiatan mengembangkan pertanian organik di Desa Ketapang, harus terus dipertahankan secara rutin, misalnya mengadakan pelatihan pembuatan pupuk organik. Selain itu, keuntungan pertanian organik secara ekonomi, perlu ditekankan lagi kepada petani dalam proses sosialisasi pertanian organik.

8) Koperasi Paguyuban Petani Al-Barokah sebaiknya dikembangkan lebih lanjut dan dimaksimalkan peranannya terhadap pemberdayaan petani di Desa Ketapang. Pengembangan koperasi mungkin dapat diarahkan menuju koperasi simpan pinjam usahatani, atau gerai khusus produk organik Desa Ketapang yang dibuka untuk masyarakat umum (konsumen organik).

9) Publikasi penelitian tentang pertanian organik hendaknya diperbanyak lagi di kalangan pemerintah, LSM, bahkan petani sebagai pedoman atau bahan sosialisasi pertanian organik kepada masyarakat.

10)Keberlanjutan praktik pertanian organik perlu mendapatkan perhatian lebih dari pemerintah, agar petani sedikit demi sedikit dapat mengurangi ketergantungannya terhadap pupuk dan pestisida kimia sintetik yang selama ini sering disubsidi oleh pemerintah.

\section{DAFTAR PUSTAKA}

Anonim. 2008. Science-Based Organic Farming 2008: Toward Local and Secure Food Systems. n.p.

Ariesusanty, Lidya. 2009. Statistik Pertanian Organik Indonesia. Bogor. Aliansi Organis Indonesia. 2008. Statistik Pertanian Organik Indonesia. Bogor. Aliansi Organis Indonesia.

HDRA-The Organic Organisation. 1998. What is Organic Farming?. United Kingdom. HDRA Publishing.

Ho, Maewan dan Ching, Lim Li. Gerakan Menuju Dunia Berkelanjutan Bebas dari Rekayasa Genetik. 2006. n.p: Independent Science Panel.

Indriana, Hana. 2010. „Kelembagaan Berkelanjutan dalam Pertanian Organik $^{\text {ee }}$ Tesis. Bogor. Departemen Sains Komunikasi dan Pengembangan Masyarakat, Institut Pertanian Bogor.

IFOAM. 2006. Organic Agriculture Worldwide Directory of IFOAM Member Organizations and Associates. Jerman. IFOAM.

Lindenlauf, Maria Müller. 2009. Organic Agriculture and Carbon Sequestration. Roma: Natural Resources Management and Environment Department Food and Agriculture Organization of the United Nations.

Mugniesyah, Siti. 2006. Materi Bahan Ajar: "Ilmu Penyuluhan (KPM 211)". Bogor. Departemen Sains Komunikasi dan Pengembangan Masyarakat, Institut Pertanian Bogor. 
Mulyani, Agus, dan Subagyo. 2003. „Penggunaan Lahan Pertanian dan Arah Pengembangan ke Depan'. Tabloid Sinar Tani. Jakarta. Sinar Tani.

Oudejans \& Martono, Edhi (Penerjemah). 2006. Perkembangan Pertanian di Indonesia. Yogyakarta. Gadjah Mada University Press.

Reijntjes, Haverkort, dan Bayer. 2006. Pertanian Masa Depan, Pengantar untuk Pertanian Berkelanjutan dengan Input Luar Rendah. Yogyakarta. Kanisius.

Rosenow, Soltysiak, dan Verschuur. 1996. Organic Farming, Sustainable Agriculture Put Into Practice. Jerman. IFOAM.

Salim, Emil. 2003. „Sains dan Pembangunan Berkelanjutan $^{\text {ee }}$. Orasi Ilmiah pada Peringatan Hari Lingkungan Hidup. Bogor. IPB.

Singarimbun, Masri dan Effendi, Sofian. 2006. Metode Penelitian Survay. Jakarta. LP3ES.

Soemarwoto, Otto. 2004. Ekologi, Lingkungan Hidup dan Pembangunan. Edisi 10. Jakarta. Djambatan.

Sugiyono. 2009. Metode Penelitian Kuantitatif Kualitatif dan R\&D. Bandung. Alfabeta.

Sulaeman, Dede. 2008. Mengenal Sistem Pangan Organik Indonesia. Jakarta. Departemen Pertanian.

2006. Perkembangan Pertanian Organik di Indonesia. Jakarta. Asosiasi Produsen Organik Indonesia.

Sutanto, Rachman. 2002. Penerapan Pertanian Organik, Pemasyarakatan \& Pengembangannya. Yogyakarta. Kanisius.

Usman, Husaini dan Akbar, Setiady. 2008. Metodologi Penelitian Sosial. Edisi 2. Jakarta. PT. Bumi Aksara.

Wahyuni, Ekawati dan Muljono, Pudji. 2007. Metode Penelitian Sosial. Bogor. Departemen Sains Komunikasi dan Pengembangan Masyarakat, Fakultas Ekologi Manusia, Institut Pertanian Bogor. 